\title{
Laser Surface Engineering of Magnesium Alloys: A Review
}

\author{
ASHISH SINGH ${ }^{1}$ and SANDIP P. HARIMKAR ${ }^{1,2}$ \\ 1.-School of Mechanical and Aerospace Engineering, Oklahoma State University, Stillwater, \\ OK 74078, USA. 2.—e-mail: sandip.harimkar@okstate.edu
}

\begin{abstract}
Magnesium ( $\mathrm{Mg}$ ) and its alloys are well known for their high specific strength and low density. However, widespread applications of $\mathrm{Mg}$ alloys in structural components are impeded by their insufficient wear and corrosion resistance. Various surface engineering approaches, including electrochemical processes (plating, conversion coatings, hydriding, and anodizing), gas-phase deposition (thermal spray, chemical vapor deposition, physical vapor deposition, diamond-like coatings, diffusion coatings, and ion implantation), and organic polymer coatings (painting and powder coating), have been used to improve the surface properties of $\mathrm{Mg}$ and its alloys. Recently, laser surface engineering approaches are attracting significant attention because of the wide range of possibilities in achieving the desired microstructural and compositional modifications through a range of laser-material interactions (surface melting, shock peening, and ablation). This article presents a review of various laser surface engineering approaches such as laser surface melting, laser surface alloying, laser surface cladding, laser composite surfacing, and laser shock peening used for surface modification of Mg alloys. The laser-material interactions, microstructural/compositional changes, and properties development (mostly corrosion and wear resistance) accompanied with each of these approaches are reviewed.
\end{abstract}

\section{INTRODUCTION}

Magnesium ( $\mathrm{Mg}$ ) is the eighth most abundant element on earth, comprising approximately $2.7 \%$ by weight of the Earth's crust. Mg exhibits excellent properties such as low density $\left(\sim 1.74 \mathrm{~g} / \mathrm{cm}^{3}\right)$ and formability (castability, workability, machinability, and weldability) important for structural applications. However, the properties that limit the widespread application of $\mathrm{Mg}$ in structural application are insufficient strength and poor resistance to heat and corrosion. Some of these properties, particularly strength, formability, and heat resistance, can be improved by alloying $\mathrm{Mg}$ with metals such as aluminum, zinc, zirconium, cerium, yttrium, silver, and thorium. Some of the best known Mg alloys are AZ91 $(9 \% \mathrm{Al}-0.7 \% \mathrm{Zn}-0.13 \% \mathrm{Mn}$; general purpose alloy with good room temperature strength and castability), AZ31 (3\%Al-1\%Zn-0.2\%Mn; good formability and weldability), AM60 (6\% Al-0.15\% Mn; good toughness and ductility), ZK60 (5-6\%Zn-0.3-0.9\%Zr; good room temperature strength and ductility, high hot workability), ZE41 (4.2\%Zn-0.7\%Zr-1.2\%rare earth element; good creep strength and heat resistance), and AS41 (4.2\% Al-1\%Si; good creep strength up to $\left.150^{\circ} \mathrm{C}\right) .{ }^{1} \mathrm{Mg}$ alloys have already started replacing steel, aluminum, and many conventional structural metal alloys in aerospace, automobile, electronics, and biomedical industries. ${ }^{2-7} \mathrm{Mg}$ alloys have been used or considered for use in motor vehicles for various parts like steering columns, engine and transmission cases/covers, and seat frames. ${ }^{6}$ These alloys have also been used to make gearbox housing for aircrafts because of their excellent vibration damping characteristics. ${ }^{8}$ Some of the recent applications of $\mathrm{Mg}$ alloys are for the cases of portable electronic devices such as telephones and computers because of their light weight, conductive and heat radiating characteristics, and ability to minimize noise by blocking electromagnetic waves. Figure 1a presents $\mathrm{Mg}$ casting shipments and also forecast from 2007 to 2019 in United States. After 2009, there was a continuous growth in the development of $\mathrm{Mg}$ and its alloys. In 2011, the total $\mathrm{Mg}$ casting shipment in United States was approximately 100,000 tons, and it is projected to be approximately 170,000 tons 

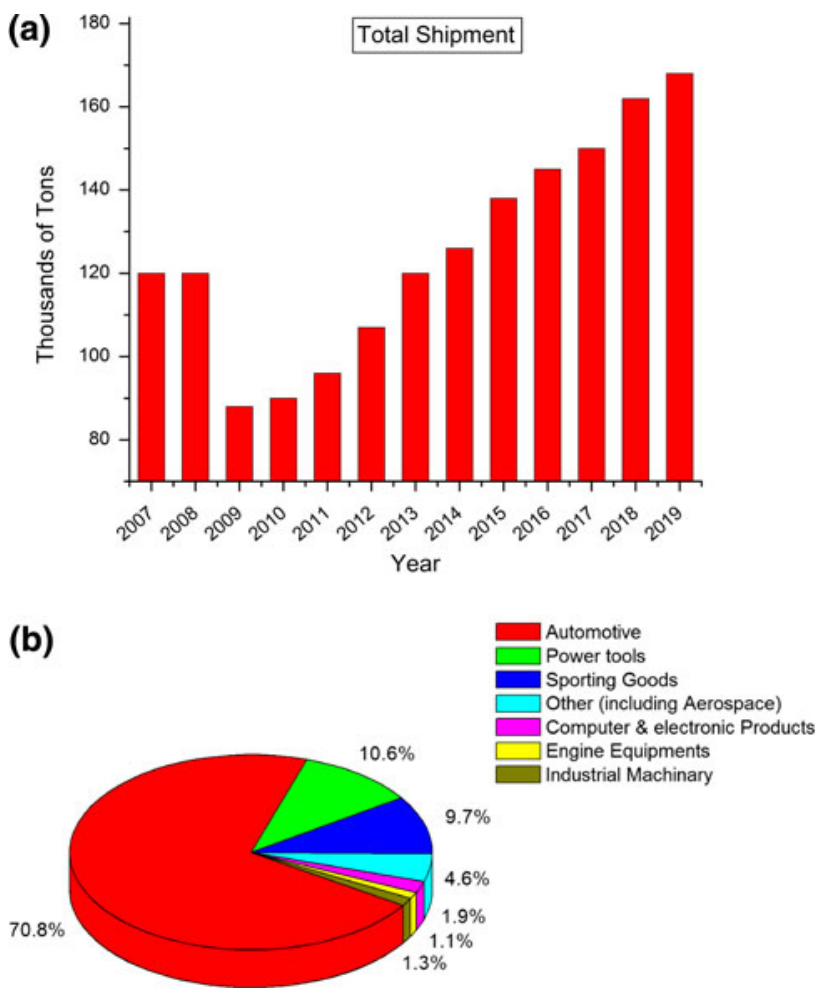

Fig. 1. (a) Mg casting shipments (and forecasts) for all market segments in United States from 2007 to 2019. (b) Classification of Mg casting shipments in United States based on different applications in the year $2008 .^{9}$

in 2019. Figure $1 \mathrm{~b}$ presents the classification of $\mathrm{Mg}$ casting shipments based on different applications. Although major uses of $\mathrm{Mg}$ are for aluminum alloying and steel desulfurization, the increase in production of $\mathrm{Mg}$ is also caused by its growing use in die cast components mostly in automotive market. ${ }^{9}$

\section{SURFACE MODIFICATION OF Mg AND ITS ALLOYS}

Whereas significant progress has been made toward improvement of bulk properties such as formability, strength, and heat/creep resistance of $\mathrm{Mg}$ by alloying, the $\mathrm{Mg}$ alloys continue to exhibit relatively poor surface properties such as wear and corrosion resistance. Improvements in wear and corrosion properties by alloying are limited because of elemental segregation and formation of undesirable brittle intermetallic phases. The surfaces of $\mathrm{Mg}$ and its alloys are often modified (both microstructural and compositional modifications) using surface engineering approaches to impart desirable properties. Several surface modification/coatings technologies, such as electrochemical processes (plating, conversion coatings, hydriding, and anodizing), gasphase deposition [thermal spray, chemical vapor deposition (CVD), physical vapor deposition (PVD), diamond-like coatings, diffusion coatings, ion implantation], and organic polymer coatings (painting and powder coating), are available to protect the surfaces of $\mathrm{Mg}$ and its alloys. These processes have recently been reviewed by Gray and Luan. ${ }^{10}$ Each process has its own advantages and disadvantages.

Electrolytic processes such as plating, conversion coatings, and anodizing are cost-effective ways of forming protective coatings on $\mathrm{Mg}$. However, electroplating techniques for effective protection of $\mathrm{Mg}$ alloys against harsh conditions like seawater or salt splash are not yet fully developed. There are important challenges in plating $\mathrm{Mg}$ alloys. For example, $\mathrm{Mg}$ alloys require significant pretreatment before plating because the highly reactive nature of $\mathrm{Mg}$ leads to the formation of oxide layers on the surface. The presence of intermetallic phases like $\mathrm{Mg}_{x} \mathrm{Al}_{y}$ in the $\mathrm{Mg}$ alloys often leads to an uneven distribution of electrochemical potential on the surface resulting in nonuniform and defective coatings. The electrolytic processes often involve the use of toxic and hazardous solutions. Limited bath life is also one limitation in the plating industry. Efforts are being made to produce cost-effective and environment friendly electrolyte solutions. ${ }^{10-13}$ Typical plating defects, such as porosity, tend to accelerate the pitting corrosion of Mg. Electroplating also limits the recycling of $\mathrm{Mg}$ because of the presence of heavy metals. Most of the developed conversion coatings cannot be used at elevated temperatures (above $65^{\circ} \mathrm{C}$ ). ${ }^{14-17}$ Anodizing results in the formation of brittle oxide layers that might not have sufficient mechanical strength for a wide range of applications. Also, most of the anodized surfaces do not offer sufficient protection as the single surface treatment, but they can form excellent presurfaces for other techniques like paints and organic coatings.

Different thermal spray techniques like plasma spraying and high-velocity oxygen fuel (HVOF) techniques have also been used for coating $\mathrm{Mg}$ and its alloys. Investigations on thermal-sprayed $\mathrm{Al}$ and $\mathrm{Al} / \mathrm{SiC}$ composites on $\mathrm{Mg}$ alloy substrates have been reported. ${ }^{18}$ The addition of $\mathrm{SiC}$ resulted in higher porosities, and no improvement in corrosion resistance was reported. Postprocessing techniques are often required to densify the coatings. The bonding achieved by thermal spray coatings is often not sufficient, and posttreatment is required to strengthen the coatings. The thermal spraying of zinc coating on $\mathrm{Mg}$ substrate was ineffective in providing sufficient protection to corrosion. Additional remelting processes (postprocessing) using laser and electron beam treatments were used to obtain high-performance coatings. ${ }^{19}$ The HVOF technique was also used to deposit WC-Co coatings on AZ91 and AE42 Mg alloy substrates. The high velocity of partially melted particles helped in attaining strong bonding and dense coating. The corrosion resistance of the coating was improved only after adding $\mathrm{Al}$ bond coating. ${ }^{20}$ Also, as thermal spraying is a line-of-sight process, it is difficult to coat intricate/internal surfaces of the substrate. 
CVD and PVD techniques can also be used to coat $\mathrm{Mg}$ and its alloys. The major advantage of using these techniques is that the components with complex shapes can be coated with excellent bonding. Christoglou et al. ${ }^{21}$ investigated a fluidized bed CVD process to deposit $\mathrm{Al}$ coatings on $\mathrm{Mg}$ substrates. The formed coatings were discontinuous with porosity, which could increase the corrosion rate. An amorphous $\mathrm{SiC}$ coating was deposited on $\mathrm{Mg}$ substrate using plasma-enhanced CVD. The immersion test performed in a simulated body fluid indicated the slowing down of the degradation of WE43 because of the presence of $\mathrm{SiC}$ amorphous coatings. In vitro tests like hemolysis test and blood platelets adhesion tests were performed on amorphous $\mathrm{SiC}$ coated WE43 to investigate their potential in biomedical applications. ${ }^{22}$ However, a major limitation of CVD is that it is difficult to coat the substrates, which are thermally unstable above $600^{\circ} \mathrm{C}$. The process also results in the formation of hazardous byproducts. $^{22,23}$ The PVD techniques were also used to deposit hard coatings on Mg substrates. Altun and $\mathrm{Sen}^{24}$ reported the deposition of dense AlN/TiN coatings on an AZ91 Mg alloy using the magnetron sputtering technique. The AlN/TiN coating resulted in the enhancement of surface hardness and wear resistance. The CVD and PVD processes require major capital investment. Also, the deposition rates are often very slow.

\section{DEVELOPMENT OF LASERS FOR SURFACE ENGINEERING}

Lasers have found diverse applications in almost all areas of materials processing, such as forming (bending, net shaping, and rapid prototyping), machining (drilling, cutting, and micromachining), welding, and surface modifications. Although the percentage of total lasers currently in use for surface modifications is quite small $(<5 \%)$, these approaches are becoming increasingly important for improving the surface properties of light alloys, biomaterials, and tribological materials. The $\mathrm{CO}_{2}, \mathrm{Nd}$ :YAG, and excimer lasers have all been used for surface modification processes. Some important advantages of laser surface engineering are noncontact processing, ease of automation, rapid processing, flexible manufacturing, minimum or no heat-affected zones, and ability to produce refined or novel microstructural features on a wide range of materials. The thermophysical properties of substrate and/or filler materials (absorptivity, thermal conductivity, melting/ boiling point, specific heat, latent heat, etc.) and laser-processing parameters (wavelength, intensity, interaction/irradiation time, and laser scanning speed) determine the nature of laser-material interactions and the extent of modified region. The final phase, microstructure, texture, and composition in the modified surface regions depends on the variety of effects of laser-material interactions including cooling rate, temperature gradients, solidification rate, convection in the melt, interfacial effects, reactions between melt and filler material, elemental evaporation, and so on. ${ }^{25}$ The laser surface engineering approaches are broadly classified into six categories based on the nature of laser-material interactions and the microstructure/compositional effects at the surfaces: laser surface heating (hardening), laser surface melting (LSM), laser surface alloying (LSA), laser composite surfacing (LCS), laser surface cladding (LSC), and laser shock peening (LSP). Most of these surface engineering approaches, except laser heating and shock peening, involve melting of substrate and/or filler material. In these cases, use of shielding gas to protect the surface from oxidation becomes very important. Also, care needs to be taken to prevent cracking of the surface during rapid solidification. Preheating of the substrate either using additional heat source or defocused laser beam before laser irradiation can be helpful. In this article, various laser surface engineering approaches used for improving the surface properties, primarily hardness, wear resistance, and corrosion resistance, of $\mathrm{Mg}$ and its alloys are reviewed. Laser surface hardening will not be discussed as it is not suitable for $\mathrm{Mg}$ alloys because of absence of rapid solid-state phase transformations at ambient pressures.

\section{Laser Surface Melting (LSM)}

In LSM, a laser with sufficiently high power density is irradiated on the material to cause localized surface melting (Fig. 2). The subsequent rapid resolidification of the laser-melted region results in the formation of refined grain structure in the modified region. The melting and resolidification occur within a very short interaction time (less than few seconds) and remain confined only to surface of the material without significantly affecting the bulk of the material. The laser can be scanned on the surface to produce overlapping parallel tracks to modify a larger area of the surface. ${ }^{26,27}$

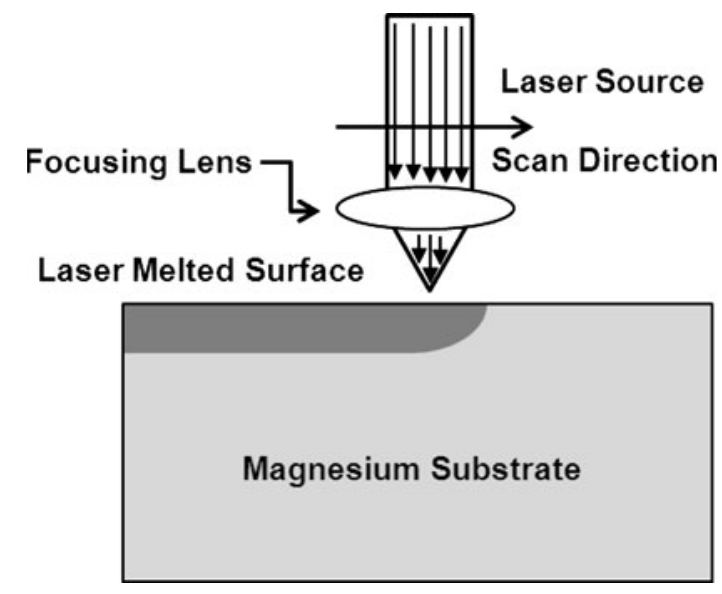

Fig. 2. Schematic of LSM process. 
Table I. Summary of processing parameters and observed depth of melting for LSM of various Mg alloys

\begin{tabular}{|c|c|c|c|c|c|c|}
\hline Mg alloy & $\begin{array}{l}\text { Laser } \\
\text { type }\end{array}$ & $\begin{array}{c}\text { Laser } \\
\text { power }(\mathbf{k W})\end{array}$ & $\begin{array}{c}\text { Scan } \\
\text { speed }(\mathbf{m m} / \mathbf{s})\end{array}$ & $\begin{array}{c}\text { Spot } \\
\text { size }(\mathbf{m m})\end{array}$ & $\begin{array}{l}\text { Overlapped } \\
\text { region }(\%)\end{array}$ & $\begin{array}{c}\text { Melted } \\
\text { depth }(\mathbf{m m})\end{array}$ \\
\hline ACM $720^{28}$ & Nd:YAG & 2 & 10 & 3.8 & 5 & 0.65 \\
\hline AZ91D $^{29}$ & Nd:YAG & 0.1 & $3-20$ & - & $50-80$ & $0.1-0.2$ \\
\hline $\mathrm{AM} 6 \mathrm{~B}^{29}$ & Nd:YAG & 0.1 & $3-20$ & - & $50-80$ & $0.1-0.2$ \\
\hline $\mathrm{AZ91HP}^{36}$ & $\mathrm{CO}_{2}$ & 3 & 50 & - & 30 & - \\
\hline $\mathrm{MEZ}^{30}$ & $\mathrm{CO}_{2}$ & $1-3$ & $100-300$ & 4 & - & $1-1.6$ \\
\hline $\mathrm{AZ31} 1^{31}$ & $\mathrm{CO}_{2}$ & 1.5 & 160 & 2 & 50 & 1 \\
\hline $\mathrm{AZ61} 1^{31}$ & $\mathrm{CO}_{2}$ & 1.5 & 160 & 2 & 50 & 1 \\
\hline WE $43^{31}$ & $\mathrm{CO}_{2}$ & 1.5 & 160 & 2 & 50 & 1 \\
\hline $\mathrm{AZ} 31^{34}$ & HPDL & 1.5 & 50 & $3.5 \times 2$ & 50 & 1 \\
\hline $\mathrm{AZ} 61^{34}$ & HPDL & 1.5 & 50 & $3.5 \times 2$ & 50 & 1 \\
\hline $\mathrm{Mg}-\mathrm{Y}-\mathrm{Zn}^{32}$ & $\mathrm{CO}_{2}$ & 2 & 28.33 & 4 & 25 & - \\
\hline
\end{tabular}

LSM has been used extensively for surface modifications of $\mathrm{Mg}$ and its alloys. The improvement in the surface properties is primarily from the formation of fine dendritic grains in the modified region. Although LSM does not introduce major compositional changes in the modified surface of $\mathrm{Mg}$ alloys, the evaporation of some of the alloying elements can occur. The depth/width of melting and grain size (dendrite arms spacing) in the modified track depends on the incident laser power, scan speed, and laser spot size (irradiation area). Table I presents the summary of laser processing parameters and observed depth of melting for LSM of various $\mathrm{Mg}$ alloys. High-power continuous-wave Nd:YAG and $\mathrm{CO}_{2}$ lasers are generally used for LSM of $\mathrm{Mg}$ alloys. Depending on the laser processing parameters, a melting depth up to $2 \mathrm{~mm}$ can be readily achieved for $\mathrm{Mg}$ alloys. In addition to the major processing parameters, the spatial distribution of energy in the incident laser beam also influences the shape of the laser-modified region (shape of melt pool) in the cross section of the laser track. A larger overlap between parallel tracks ( $>25 \%$ of the track width) is often needed to achieve a uniform depth of melting over a larger area. The microstructure in the overlapped region is generally different than the larger modified surface and may result in nonuniform surface properties. The microstructural and compositional uniformity in the laser-modified surfaces can be improved by minimizing the overlapped regions. The spatial distribution of energy in the incident beam can be shaped to some extent to achieve desired shapes of the melt pools and minimize the track overlap $(<5 \%){ }^{28}$ Because of the highly reactive nature of $\mathrm{Mg}$ alloys, the LSM experiments are generally performed under shielding inert gases to avoid undesirable surface oxidation and reactions.

\section{Microstructure Analysis}

As-cast Mg alloys are generally characterized by a coarse microstructure (grain size in the range of 50 $250 \mu \mathrm{m})$ consisting of primary $\alpha-\mathrm{Mg}$ and lamellar eutectic ( $\alpha-\mathrm{Mg}+$ intermetallic) phases. LSM of $\mathrm{Mg}$ alloys results in significant grain refinement with grain size in the range of $1-10 \mu \mathrm{m}$. The rapid solidification rates associated with LSM often favor the formation of partially or fully divorced eutectic (separation of eutectic phases) and dendritic/ columnar primary $\alpha$-Mg. LSM also results in compositional changes caused by the selective evaporation of elements like $\mathrm{Mg}$ and $\mathrm{Zn}$, and consequent enrichment of elements like $\mathrm{Al}$ in the laser-melted region. Such compositional changes often influence the corrosion behavior of laser-melted alloys. LSM of AZ91 and AM60B was investigated by Dube et al. $^{29}$ LSM resulted in grain refinement and the formation of a fine network of dendrites as a result of the high cooling rates attained in laser processing. In addition, the dendrites on the surface were finer $(<1 \mu \mathrm{m})$ than those near the interface because of the decreasing cooling rate along the depth of the melt. LSM also resulted in enrichment of $\mathrm{Al}$ at the surface because of the selective evaporation of $\mathrm{Mg}$. However, no change in the average elemental concentration of $\mathrm{Fe}, \mathrm{Ni}$, and $\mathrm{Cu}$ was observed after laser melting. LSM of MEZ $(0.5 \% \mathrm{Zn}-0.1 \% \mathrm{Mn}-0.1 \% \mathrm{Zr}$ $2 \%$ rare earth) resulted in refinement of the grains in a defect- and crack-free microstructure. Enrichment of $\mathrm{Zn}$ and $\mathrm{Ce}$ along the grain boundaries was also observed. However, no peaks corresponding to free $\mathrm{Zn}$ and $\mathrm{Ce}$ were observed in the x-ray diffraction (XRD) patterns from the melted surface indicating the formation of complex structures of $\mathrm{Mg}$, $\mathrm{Zn}$, and $\mathrm{Ce}$ along the grain boundaries. ${ }^{30}$ Abbas et al. ${ }^{31}$ performed LSM of AZ31, AZ61, and WE43 alloys, and they reported no significant change in composition after laser melting, which contradicted previous studies. Mondal et al. ${ }^{28}$ investigated LSM of ACM720 alloy and reported significant grain refinement in the laser-melted region (grain size in the range of 1.5-7 $\mu \mathrm{m}$ in laser-melted region compared with $40-135 \mu \mathrm{m}$ in the as-cast alloy). Figure $3 \mathrm{a}$ shows the cross section of laser-melted ACM720 alloy where a defect-free interface can be observed. Figure $3 \mathrm{~b}$ and $\mathrm{c}$ shows the microstructure 

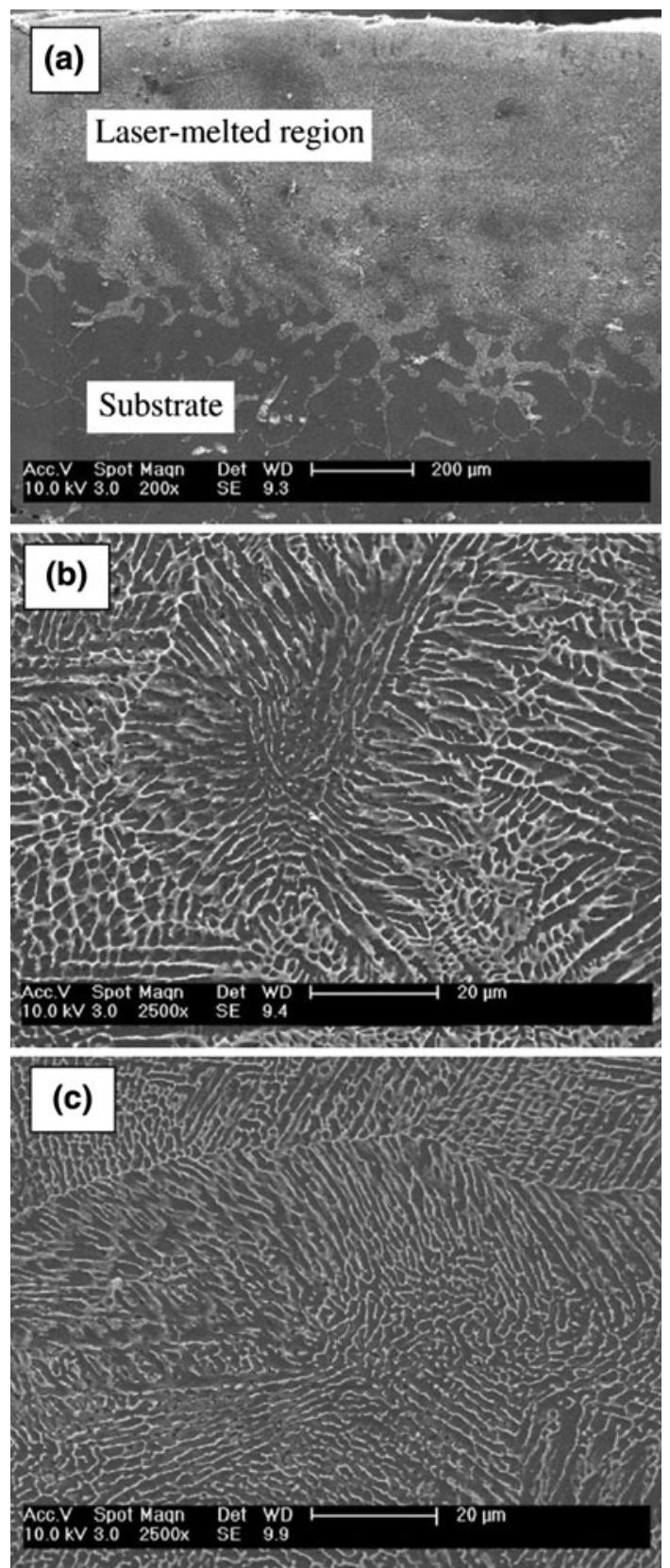

Fig. 3. SEM micrographs from laser surface melted ACM 720 alloy: (a) cross section showing interface, (b) magnified view of laser-melted region in cross section, and (c) magnified view of laser-melted region in top surface ${ }^{28}$ (Reprinted with permission from Elsevier).

in the cross section and top surface of the lasertreated region where refined grains were observed. The microstructure consisted of mixed cellular and dendritic grains with a mean dendritic arm spacing of $2 \mu \mathrm{m}$. An XRD analysis indicated the presence of phases like $\alpha-\mathrm{Mg}, \mathrm{Al}_{8} \mathrm{Mn}_{5}$, and $\mathrm{Ca}_{31} \mathrm{Sn}_{20}$ in the laser-melted surface. The rapid melting and solidification during LSM resulted in the dissolution of $\mathrm{Al}_{2} \mathrm{Ca}$ phase, which was present in the as-cast alloy. In addition, the $\mathrm{Mg}_{17} \mathrm{Al}_{12}$ phase was not observed in

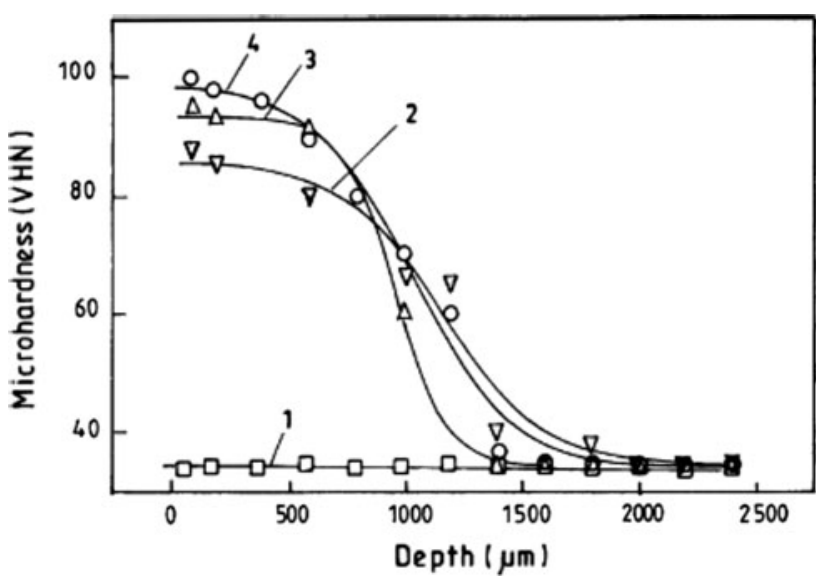

Fig. 4. Microhardness as a function of depth from the surface: (1) as-received MEZ; and laser surface melted MEZ with (2) laser power of $2 \mathrm{~kW}$ and scan speed of $200 \mathrm{~mm} / \mathrm{min}$, (3) laser power of $2.0 \mathrm{~kW}$ and scan speed of $300 \mathrm{~mm} / \mathrm{min}$, and (4) laser power of $1.5 \mathrm{~kW}$, scan speed of $200 \mathrm{~mm} / \mathrm{min}^{30}$ (Reprinted with permission from Elsevier).

the laser-melted region indicating suppression of intermetallic formation during rapid solidification. The suppression of such intermetallic formation is known to enhance the creep properties of $\mathrm{Mg}$ alloys. It was also observed that the content of $\mathrm{Mg}$ decreased in the laser-melted region as a result of selective evaporation.

\section{Hardness and Wear Resistance}

LSM of Mg alloys results in high surface hardness (approximately 2-4 times the hardness of as-cast alloy) as a result of grain refinement and solidsolution strengthening effects (because of solute supersaturation with rapid cooling or solute enrichment with selective evaporation of elements). The microhardness gradually decreases from the surface toward the bulk of the sample because of progressive coarsening of the dendritic microstructure. Lv et al. ${ }^{32}$ observed four regions in the lasersurface melted zone of a Mg alloy: (I) The top layer with the highest hardness and finest dendrite size; (II) the intermediate layer with coarser dendrites and moderate hardness values; (III) the heat-affected zone; and (IV) the substrate with the lowest hardness. Majumdar et al. ${ }^{30}$ investigated the effect of laser power and scan speed on microhardness of MEZ alloys. The maximum surface hardness of $100 \mathrm{HV}$ was reported with a laser power of $1.5 \mathrm{~kW}$ and a scan speed of $200 \mathrm{~mm} / \mathrm{min}$. A higher laser power $(2 \mathrm{~kW})$ resulted in a coarser surface microstructure and lower hardness because of slower cooling rates and overlapping of tracks (Fig. 4). A finer microstructure and higher surface hardness can be achieved with faster laser scanning, which results in higher cooling rates. Liu et al. ${ }^{33}$ also investigated the microhardness of laser surface melted $\mathrm{Mg}$ alloy (8.57\%Al-0.68\% Zn-0.15\%Mn$0.52 \mathrm{Ce}$ ) along the cross section. The hardness of 


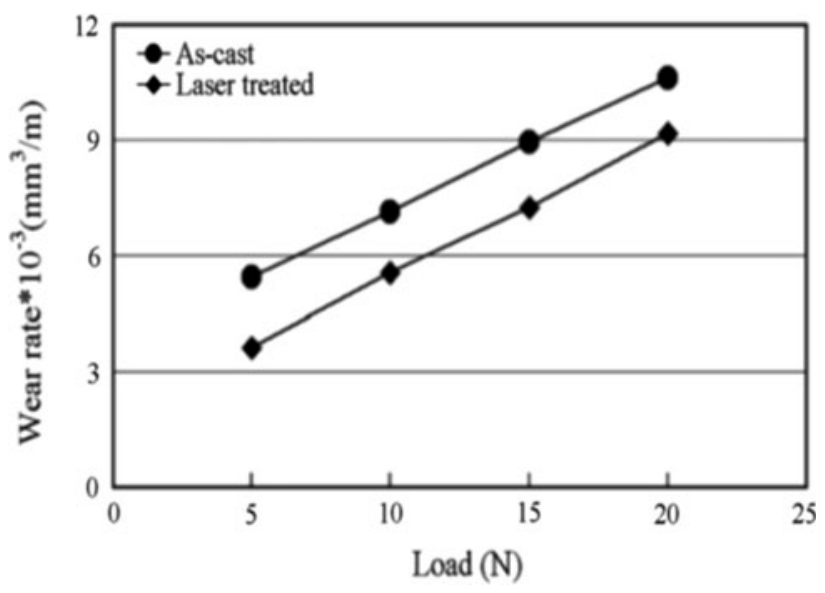

Fig. 5. Variation of wear rate for as-cast and laser-treated ACM $720 \mathrm{Mg}$ alloy with load ${ }^{28}$ (Reprinted with permission from Elsevier).

laser-melted surface (150 HV) was significantly higher than that of substrate $(75 \mathrm{HV})$. No rapid drop in the hardness profile was observed, indicating the presence of a heat-affected zone.

An increase in surface hardness also results in an improvement in the wear resistance of laser-melted $\mathrm{Mg}$ alloys. The wear behavior of laser-melted ACM $720 \mathrm{Mg}$ alloy was investigated by Mondal et al. ${ }^{28}$ over a wide range of normal loads $(5-20 \mathrm{~N})$. The wear rate of laser-melted samples was significantly lower than that of as-cast samples at all the loads (Fig. 5). Both microploughing and microcutting features characteristic of abrasive wear mechanisms were observed on the wear track. Majumdar et al. $^{30}$ also investigated the wear behavior of laser surface melted MEZ alloys. LSM resulted in improvements in wear resistance because of the increase in microhardness and grain refinement. The wear resistance of laser surface melted AZ31 and AZ61 was analyzed by Abbas et al. ${ }^{31,34}$ It was reported that the formation of $\beta-\mathrm{Mg}_{17} \mathrm{Al}_{12}$ resulted in better wear resistance of laser-surface melted alloys. This hard intermetallic phase seems to act as a barrier for the propagation of microcracks, scoring, and plastic deformation during wear. Lv et al. ${ }^{32}$ investigated friction and wear behavior of lasertreated Mg-Y-Zn alloys. The coefficient of friction and wear rate were obtained for different loads ranging from $20 \mathrm{~N}$ to $320 \mathrm{~N}$. A very high coefficient of friction of approximately 0.9 was observed for $20 \mathrm{~N}$ load, but a subsequent increase in load resulted in a decrease in coefficient of friction (to as low as 0.2) and increase in wear rate. This was primarily caused by the frictional heat-induced softening of a $\mathrm{Mg}$ alloy at higher loads. Even though the surface microstructure of the as-cast and lasersurface melted samples were different, the coefficients of friction for both the samples were comparable. It was reported that the effect of grain refinement and high hardness was minimized by the increase in temperature at higher loads, resulting in comparable coefficients of friction for both samples. In addition, the plastic deformation zone extended beyond the laser-melted layer on the substrate, and the accumulation of debris on the wear track mitigated the effect of laser surface treatment. The wear resistance of the laser-melted surface increased significantly because of the formation of $\mathrm{Mg}_{12} \mathrm{ZnY}$, which reduced the tendency of crack formation on the wear track.

\section{Corrosion Resistance}

Guo et al. ${ }^{35}$ examined the corrosion behavior of laser-melted WE43 (4.1\%Y-2.3\% Nd-1.0\%RE$0.5 \% \mathrm{Zr}$ ). LSM was performed by varying the laser scan speed between $2 \mathrm{~mm} / \mathrm{s}$ and $10 \mathrm{~mm} / \mathrm{s}$ while keeping the laser power density constant $\left(6 \mathrm{~J} / \mathrm{cm}^{2}\right)$. A pitting corrosion attack was observed on the surface of untreated surface with the formation of $\mathrm{Mg}(\mathrm{OH})_{2}$. The laser-melted WE43 surface looked corrosion free even after $4 \mathrm{~h}$ of immersion in $3.5 \%$ $\mathrm{NaCl}$. The lowest corrosion current was observed for the laser surface melted alloy with the slowest scan speed. The decrease in both anodic and cathodic current was observed indicating an enhancement of the corrosion resistance. It was reported that the formation of oxides and nitrides of $\mathrm{Mg}$ resulted in decrease in anodic current, whereas the dissolution of $\mathrm{Mg}_{12} \mathrm{Nd}$ during laser melting resulted in a decrease in cathodic current. The effects of LSM on corrosion resistance of different $\mathrm{Mg}$ alloys, AZ31, AZ61, and WE43, were also examined. The laser melting was conducted with a laser power of $1.5 \mathrm{~kW}$ and scan speed of $160 \mathrm{~mm} / \mathrm{s}$ with track overlapping of $50 \%$. The alloy AZ61 showed better corrosion resistance than AZ31 primarily because of a higher percentage of aluminum in AZ61. The alloy WE43 showed superior corrosion resistance because of the presence of rare earth element on the surface. Improved corrosion resistance of these three alloys was attributed to the refinement of $\alpha-\mathrm{Mg}$ grains and uniform redistribution of $\beta$-phase after laser treatment. ${ }^{31}$ The corrosion resistance of laser-melted AZ91HP was reported to be increased because of a decrease in size of $\alpha-\mathrm{Mg}$ dendrites from 150-250 $\mu \mathrm{m}$ in as-cast samples to 1-4 $\mu \mathrm{m}$ in laser-melted samples. In addition, the corrosion resistance also increased with the enrichment of aluminum content in the laser-melted zone because of the selective evaporation of $\mathrm{Mg}$. A significant difference in microstructure and corrosion behavior of overlapping and nonoverlapping zone was observed. The overlapped region, which was affected by remelting during adjacent laser scan, exhibited a higher corrosion rate. ${ }^{36}$ The corrosion behavior of laser-melted AZ91D and AM60B was also investigated. Contrary to the expectations, not much improvement in corrosion resistance was observed for the laser-melted zone. However, significant grain refinement was observed in the laser-melted region. It was reported that the concentration of $\mathrm{Mg}_{17} \mathrm{Al}_{12}$ increased after laser treatment, which contradicts the previous 

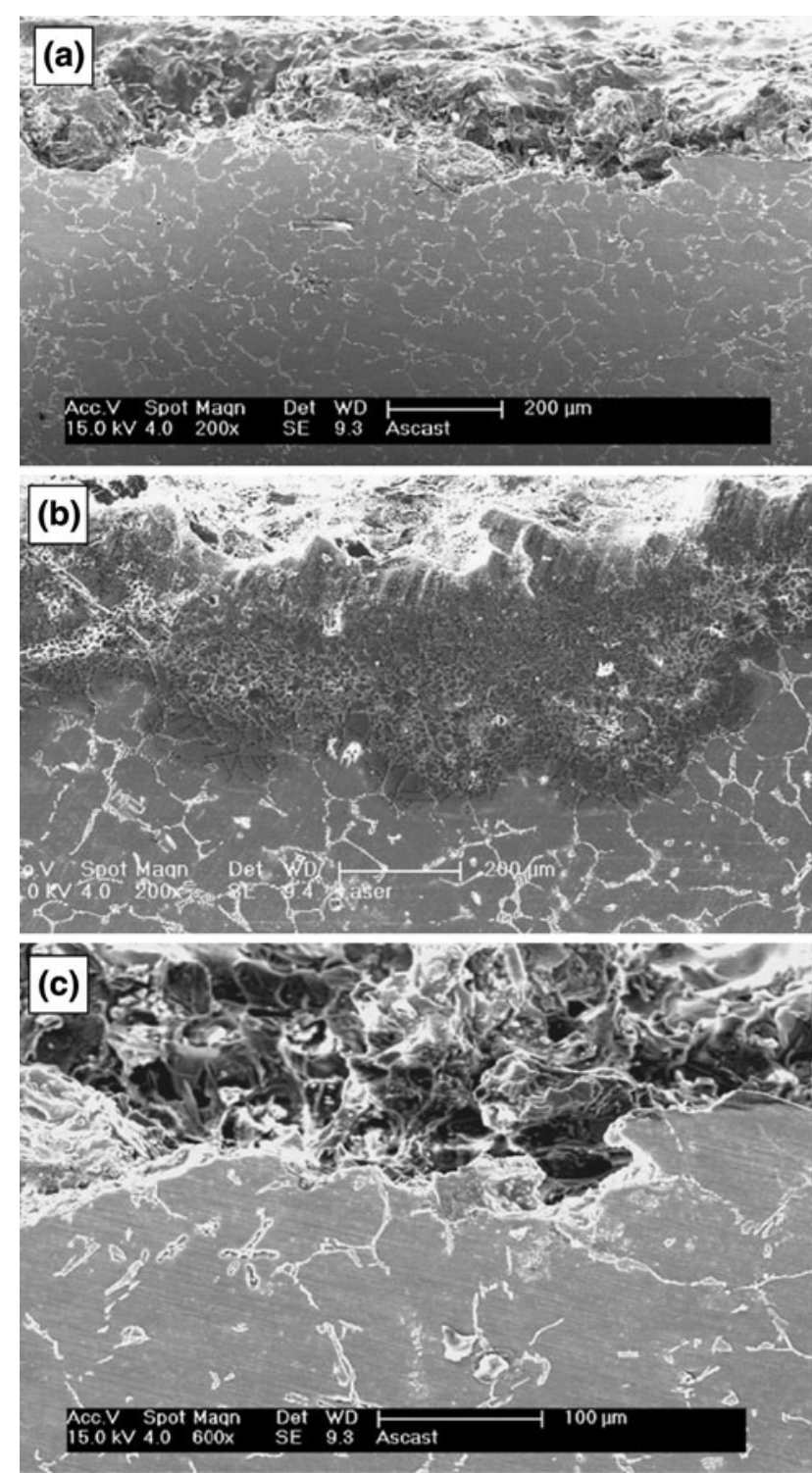

Fig. 6. Cross-sectional micrographs of the corroded surface of ACM720 alloy in (a) as-cast condition and (b) after laser surface treatment. A high-magnification view of corroded region in (a) is also shown in (c) ${ }^{28}$ (Reprinted with permission from Elsevier). reports suggesting the suppression of intermetallic formation or dissolution of intermetallic phase during LSM of Mg alloys. The decrease in corrosion resistance of AZ91D and AM60B alloys after LSM in this investigation was attributed to the increased content of $\mathrm{Mg}_{17} \mathrm{Al}_{12}$ intermetallic phase. The presence of tensile residual stresses was also cited for increased corrosion rate of lasermelted alloys. It is well known that accelerated corrosion can occur under stress. $^{29,37}$ The corrosion behavior of lasertreated and as-received ACM720 Mg alloy was also investigated by Mondal et al. ${ }^{28}$ A slight improvement in corrosion resistance for laser-treated samples was observed in this investigation. A discontinuous $\mathrm{Mg}(\mathrm{OH})_{2}$ layer was observed on the corroded region of base alloy, whereas the $\mathrm{Mg}(\mathrm{OH})_{2}$ layer was more stable on the laser-melted surface. Cross-sectional micrographs of the corroded samples of as-cast and laser-melted ACM720 samples are presented Fig. 6. A lower depth of corrosion attack on a laser-treated sample indicated an improvement in corrosion resistance. The improvement in corrosion resistance was attributed to grain refinement, absence of $\mathrm{Al}_{2} \mathrm{Ca}$ phase, and $\mathrm{Al}$ enrichment in the laser-melted zone. A significant difference in the corrosion depths for as-cast and lasermelted samples was observed.

\section{Laser Surface Alloying (LSA)}

In LSA, preferred alloying elements are added to the melt pool to modify the surface composition. The alloying element can be introduced in two different ways: direct injection and preplaced coating (Fig. 7). In the direct injection method, the alloying elements in the form of a fine powder or wire are directly fed into the laser-melted pool. Alternatively, the alloying elements can be preplaced on the base material in the form of adherent or nonadherent coating (such as foils, pastes or powder slurries) followed by laser surface melting. The laser irradiation on the surface causes melting of alloying elements (injected or preplaced) and surface of base material resulting in an enriched melt pool, which subsequently solidifies to

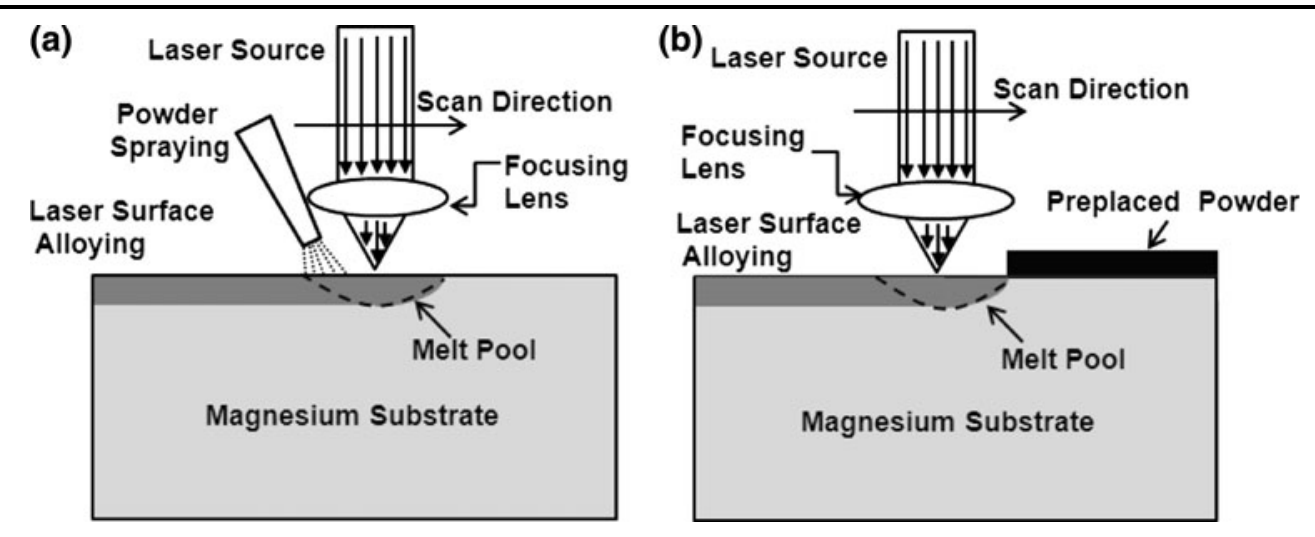

Fig. 7. Schematic of LSA: (a) direct powder injection and (b) preplacement of alloying element using organic binder. 
Table II. Summary of hardness and microstructural features achieved for various Mg alloys laser surface alloyed with different alloying elements

\begin{tabular}{|c|c|c|c|}
\hline Substrate & Alloying element & Hardness (HV) & General microstructure/intermetallic phase \\
\hline $\mathrm{Mg}^{39}$ & $\mathrm{Al}$ & 100 & Eutectic fibers $/ \mathrm{Mg}_{17} \mathrm{Al}_{12}$ \\
\hline $\mathrm{Mg}^{39}$ & $\mathrm{Ni}$ & 300 & Oriented dendrites $/ \mathrm{Mg}_{2} \mathrm{Ni}$ \\
\hline $\mathrm{Mg}^{39}$ & $\mathrm{Al}+\mathrm{Cu}$ & 370 & Faceted dendrites $/(\mathrm{Al}, \mathrm{Cu})_{2} \mathrm{Mg}$ \\
\hline $\mathrm{Mg}^{39}$ & $\mathrm{Al}+\mathrm{Cu}$ & 270 & Long faceted dendrites $/(\mathrm{Al}, \mathrm{Cu})_{2} \mathrm{Mg}$ \\
\hline $\mathrm{Mg}^{39}$ & $\mathrm{Al}+\mathrm{Ni}$ & 290 & Long armed dendrites $/ \mathrm{Al}_{3} \mathrm{Ni}_{2}$ and $\mathrm{Al}_{3} \mathrm{Mg}_{2}$ \\
\hline $\mathrm{Mg}^{39}$ & $\mathrm{~Pb}$ & 80 & Dendrites \\
\hline $\mathrm{Mg}^{39}$ & $\mathrm{Sn}$ & 90 & Dendrites \\
\hline $\mathrm{Mg}^{39}$ & $\mathrm{Zn}$ & 70 & Grain boundaries \\
\hline $\mathrm{Al} 80^{39}$ & $\mathrm{Cu}$ & 230 & Oriented dendrites \\
\hline $\mathrm{Al} 80^{39}$ & $\mathrm{Ni}$ & 250 & Oriented dendrites \\
\hline WE5 $4^{39}$ & $\mathrm{Cu}$ & 230 & Needle-shaped dendrites \\
\hline WE54 $4^{39}$ & $\mathrm{Ni}$ & 300 & Needle-shaped dendrites \\
\hline $\mathrm{AZ} 61^{39}$ & $\mathrm{Cu}$ & 220 & Dendrites \\
\hline $\mathrm{AZ} 61^{39}$ & $\mathrm{Si}$ & 220 & Dendrites \\
\hline $\mathrm{AZ}_{31 \mathrm{~B}^{43}}$ & $\mathrm{Al}$ & & $\mathrm{Mg}_{17} \mathrm{Al}_{12}, \mathrm{Al}_{2} \mathrm{O}_{3}, \mathrm{MgO}_{2}$ \\
\hline $\mathrm{AZ} 91 \mathrm{D}^{41}$ & $\mathrm{Al}+\mathrm{Si}$ & 300 & $\mathrm{Mg}_{2} \mathrm{Si}, \mathrm{Al}_{12} \mathrm{Mg}_{17}, \mathrm{Al}_{3} \mathrm{Mg}_{2}$ \\
\hline $\mathrm{AZ} \mathrm{DD}^{40}$ & $\mathrm{Si}$ & - & $\mathrm{Mg}_{2} \mathrm{Si}, \mathrm{Mg}_{17} \mathrm{Al}_{12}$ \\
\hline $\mathrm{AZ91}^{42}$ & $\mathrm{Ni}$ & $150-300$ & $\mathrm{Mg}_{2} \mathrm{Ni}$ \\
\hline
\end{tabular}

form an alloyed surface layer. Very high cooling rates, up to $10^{11} \mathrm{~K} / \mathrm{s}$, during resolidification result in a refined microstructure in the alloyed surface. The desired metallurgical and mechanical properties in the alloyed surfaces stem from a combination of effects including microstructure refinement, solidsolution strengthening, and formation of hard phases. The depth of alloyed layer and extent of alloying depends on laser processing parameters such as laser power, scan speed, laser spot size, and injection rate of alloying elements (or thickness of preplaced layer). ${ }^{26,38}$ The laser processing parameters need to be carefully optimized to ensure complete melting of alloying elements and formation of strong metallurgical bonding between alloyed layer and substrate.

\section{Microstructure Analysis}

LSA of $\mathrm{Mg}$ and its alloys has been extensively studied by Galun and Mordike. ${ }^{39}$ They used both one-step (direct powder injection) and two-step (preplacement of alloying element using organic binder followed by LSM) processes to alloy the surfaces of $\mathrm{Mg}$ and alloy substrates using different alloying elements and their combinations $(\mathrm{Al}, \mathrm{Cu}$, $\mathrm{Ni}, \mathrm{Si}, \mathrm{Al}+\mathrm{Cu}, \mathrm{Al}+\mathrm{Ni}$, and $\mathrm{Al}+\mathrm{Si}$ using one-step process, and $\mathrm{Sn}, \mathrm{Pb}$, and $\mathrm{Zn}$ using two-step process). The results of these LSA experiments are presented in Table II. Depending on the extent of alloying, the microstructure of the alloyed surface consisted of single-phase hard intermetallic or two-phase mixture of primary dendrites and eutectic (with intermetallic as one of the constituent phases). The hardness of the laser-alloyed surface layer primarily depends on the nature of intermetallic phase (composition, melting point, and relative percentage) and microstructural aspects (dendritic grain size, orientation, and phase distribution). Murayama et al. ${ }^{40}$ reported LSA of AZ91D using Si powder as an alloying element. LSA experiments were performed by varying the laser power and number of passes. A phase analysis of the laser-treated surface showed that the molten $\mathrm{Mg}$ reacted with $\mathrm{Si}$ to form $\mathrm{Mg}_{2} \mathrm{Si}$. Unreacted Si particles in the alloyed layer and surface cracking were observed for insufficient laser power or scan time. Multipass laser processing enhanced the reactions between the melt substrate and injected silicon powder during surface alloying. LSA of Al-Si on AZ91D resulted in the formation of $\mathrm{Mg}_{2} \mathrm{Si}, \mathrm{Al}_{12} \mathrm{Mg}_{17}$, and $\mathrm{Al}_{3} \mathrm{Mg}$ phases. Unreacted $\mathrm{Al}$ and Si were also detected by XRD. ${ }^{41}$ Majumdar and Manna $^{42}$ investigated LSA of AZ91 with $\mathrm{Ni}$. In addition to primary $\mathrm{Mg}$ and intermetallic $\mathrm{Mg}_{2} \mathrm{Ni}$, some unreacted/excess $\mathrm{Ni}$ was also observed in the alloyed surface layer. The nanocrystalline nature of the $\mathrm{Mg}_{2} \mathrm{Ni}$ phase was confirmed by transmission electron microscopy (TEM) selected area diffraction analysis. Interestingly, the presence of $\mathrm{Mg}_{12} \mathrm{Al}_{17}$ phase was completely suppressed in the alloyed surface because a low heat of formation favors its dissociation. Paital et al. ${ }^{43}$ investigated LSA of AZ31B with Al. The different phases observed on the surface after LSA were $\mathrm{Mg}, \mathrm{Al}, \mathrm{Al}_{12} \mathrm{Mg}_{17}, \mathrm{MgO}_{2}$, and $\mathrm{Al}_{2} \mathrm{O}_{3}$. The laser processing in the atmospheric conditions resulted in formation of the hard oxide phases $\left(\mathrm{MgO}_{2}\right.$ and $\left.\mathrm{Al}_{2} \mathrm{O}_{3}\right)$ on the surface. Figure 8 shows the distribution of $\mathrm{Al}_{12} \mathrm{Mg}_{17}$ intermetallic phase in the $\alpha-\mathrm{Mg}$ matrix and unreacted $\mathrm{Al}$ as nanoparticles. The refinement of $\alpha-\mathrm{Mg}$ grains from $10-20 \mu \mathrm{m}$ in as-received sample to approximately $1-2 \mu \mathrm{m}$ in the laser-alloyed surface was also observed because of the high cooling rate. Chen et al. ${ }^{44}$ reported LSA of ZM5 Mg alloy with Al. The alloyed zone mainly consisted of $\mathrm{Al}$ and eutectic of $\mathrm{Mg}$ and 


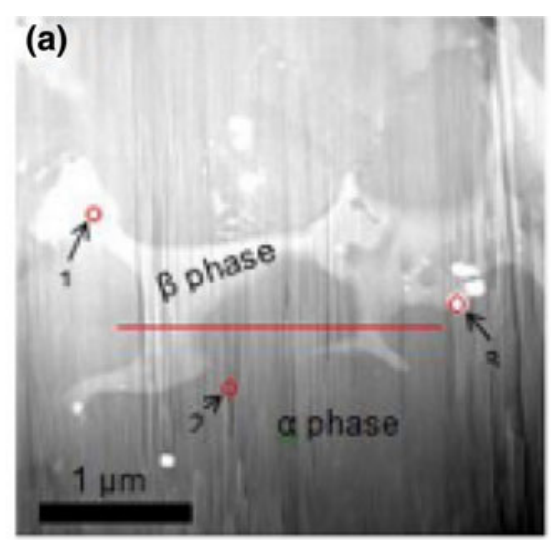

(c)
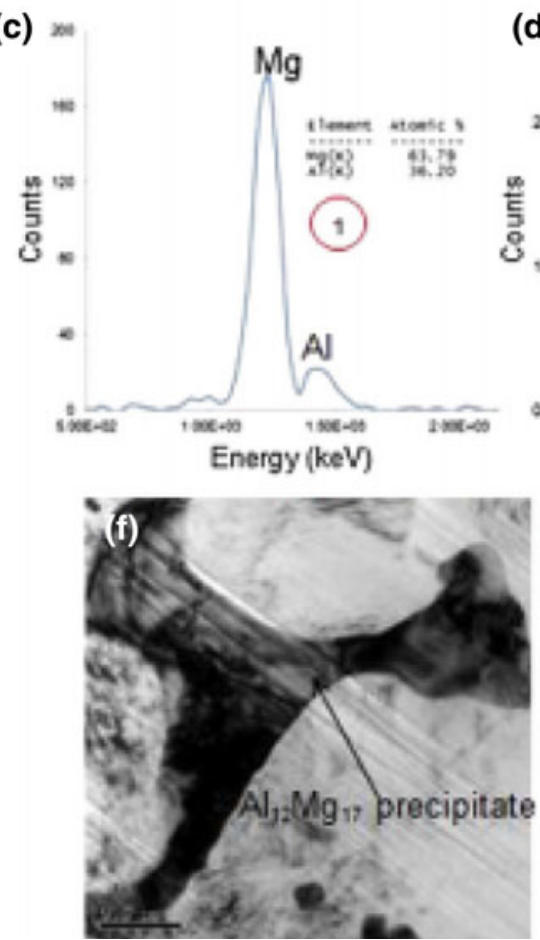

(d)
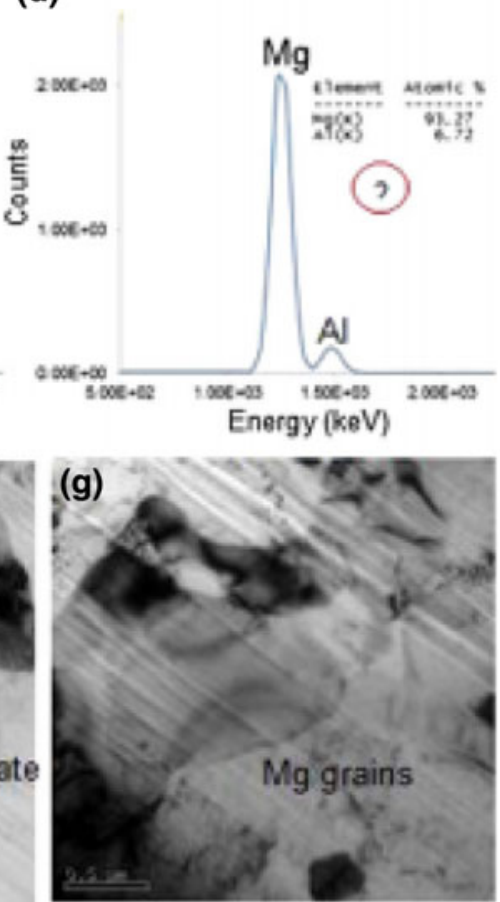

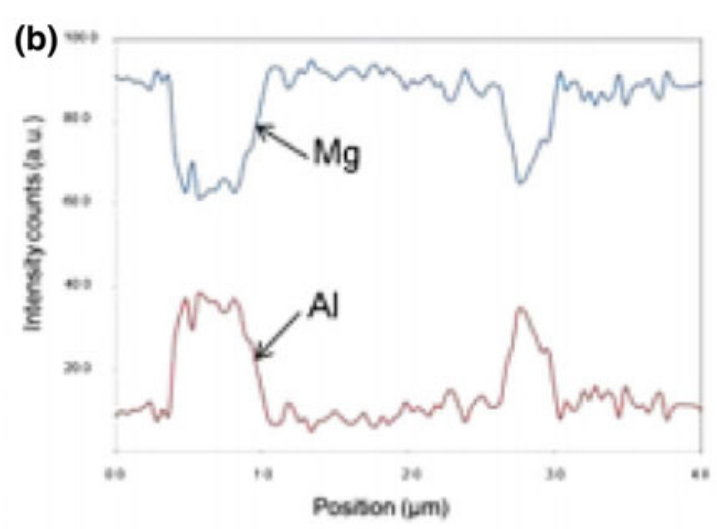

(e)
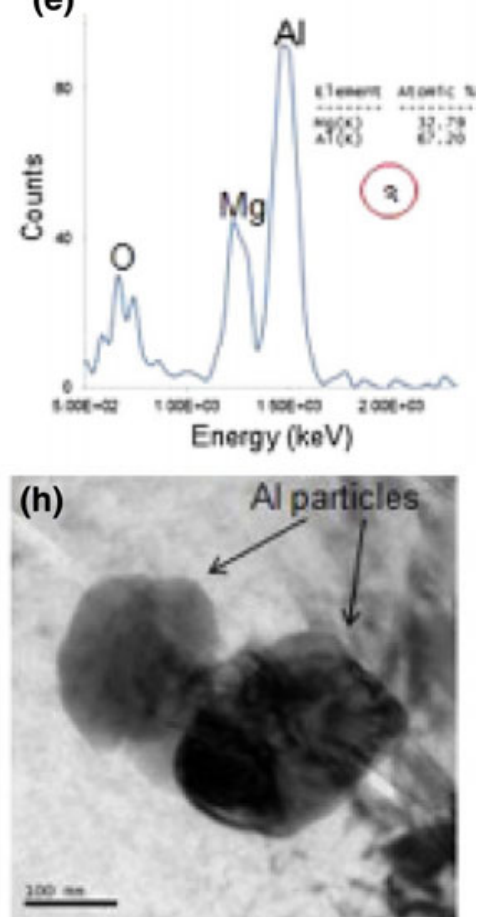

Fig. 8. (a) Low-magnification TEM image, (b-e) EDS analysis of selected line and spots, $(\mathrm{f}-\mathrm{h})$ high-resolution TEM bright-field image of the $\mathrm{Al}_{12} \mathrm{Mg}_{17}$ intermetallic phase, $\alpha-\mathrm{Mg}$ grains, and Al-rich nanoparticles, respectively, for the sample processed with laser fluence of $8.9 \times 10^{8} \mathrm{~W} / \mathrm{m}^{2}$; see Ref. 43 (Reprinted with permission from Elsevier).

$\mathrm{Mg}_{17} \mathrm{Al}_{12}$. Table II presents a summary of microhardness and microstructural features achieved for various $\mathrm{Mg}$ alloys surface alloyed with different alloying elements.

\section{Hardness and Wear Resistance}

LSA of AZ91D substrate (hardness $\sim 50 \mathrm{HV}$ ) using Al-Si was investigated by Ming et al. ${ }^{41}$ The microhardness of the laser-alloyed surface was found to be in the range of 220-340 HV. The increase in hardness was mainly caused by the formation of intermetallics like $\mathrm{Mg}_{2} \mathrm{Si}, \mathrm{Al}_{12} \mathrm{Mg}_{17}$, and $\mathrm{Al}_{3} \mathrm{Mg}_{2}$, as well as grain refinement in the alloyed region. Although the hardness gradually decreased from the surface into the alloyed region, there was a sharp drop in microhardness at the fusion point. Galun and Mordike ${ }^{39}$ performed microhardness tests on various laser-alloyed $\mathrm{Mg}$ substrates, and the hardness values were reported (Table II). The hardness of the laser-alloyed surfaces increased because of the formation of various hard phase intermetallics and grain refinement in the alloyed region. Majumdar and Manna ${ }^{42}$ investigated the microhardness and Young's modulus of AZ91 laser alloyed with $\mathrm{Ni}$. The formation of $\mathrm{Mg}_{2} \mathrm{Ni}$ phase resulted in an increase in microhardness from 70 VHN (substrate) to $150-300$ VHN. The Young's modulus of the laser-alloyed surface was in the range of 40-85 GPa, whereas for the base metal it was $45 \mathrm{GPa}$. Clearly, LSA resulted in increase in microhardness and Young's modulus. 
Murayama et al. ${ }^{40}$ investigated the influence of the fractional area of $\mathrm{Mg}_{2} \mathrm{Si}$ on the wear performance of the laser-alloyed $\mathrm{Mg}$ alloy with Si. The increase in fractional area up to $50 \%$ resulted in increase in wear resistance; thereafter, the wear properties deteriorated because of the excessive brittleness in the laser-alloyed region associated with the formation of hard/brittle $\mathrm{Mg}$-Al intermetallic compounds. Paital et al. ${ }^{43}$ investigated wear behavior of laser alloyed AZ31B with Al. Wear test data showed that LSA resulted in a significant reduction in weight loss. The unalloyed substrate showed a 2-6 times increase in cumulative weight loss compared with laser-alloyed samples. Majumdar and Manna ${ }^{42}$ investigated wear response of laser-alloyed AZ91 with Ni. The improvement of wear resistance was observed due to laser alloying with $\mathrm{Ni}$. The wear weight loss decreased from $7.6 \mathrm{mg} /$ $\mathrm{mm}^{2}$ for the substrate to $3.8 \mathrm{mg} / \mathrm{mm}^{2}$ for the laseralloyed surface. The formation and dispersion of $\mathrm{Mg}_{2} \mathrm{Ni}$ phase and grain refinement resulted in better wear properties of laser-alloyed AZ91 with $\mathrm{Ni}$.

\section{Corrosion Resistance}

Corrosion behavior of laser-alloyed $\mathrm{Mg}$ substrate with $\mathrm{Al}, \mathrm{Cu}, \mathrm{Ni}, \mathrm{Si}$, and a combination of these metals was studied by Galun and Mordike. ${ }^{39}$ LSA with $\mathrm{Al}$ and $\mathrm{Ni}$ showed better corrosion resistance. Such an improvement was not observed when copper was laser alloyed on $\mathrm{Mg}$ substrate. Localized corrosion was also observed after LSA with $\mathrm{Al}+\mathrm{Cu}$. The samples laser surface alloyed with $\mathrm{Al}+\mathrm{Cu}$ showed corrosion attack, which was similar to that for copper-alloyed samples. The alloying of $\mathrm{Mg}$ with $\mathrm{Al}+\mathrm{Ni}$ and $\mathrm{Al}+\mathrm{Si}$ resulted in better corrosion resistance than those alloyed with other combinations of binary alloying elements. Ming et al. ${ }^{41}$ investigated the microstructure development and corrosion response of laser-surface alloyed AZ91D with Al-Si. Anodic polarization tests were carried out to investigate the corrosion behavior of the laser-alloyed surface using $3.5 \% \mathrm{NaCl}$. The corrosion potential value was $435 \mathrm{mV}$ higher and the corrosion current was an order of magnitude lower for the alloyed layer than that for the substrate. The main reason for the increase in corrosion resistance was the formation of distributed intermetallics compounds like $\mathrm{Mg}_{2} \mathrm{Si}, \gamma-\mathrm{Al}_{12} \mathrm{Mg}_{17}$, and $\beta-\mathrm{Al}_{3} \mathrm{Mg}_{2}$. The corrosion was mostly observed in the matrix composed of $\alpha-\mathrm{Mg}$ and $\mathrm{Al}$ solid solutions. The dense intermetallic compounds were mostly not affected, even though corrosion effects on these particles were observed at some locations. Paital et al. ${ }^{43}$ investigated corrosion behavior of laser-alloyed AZ31B with Al using potentiodynamic polarization experiments. Nobler corrosion potential was observed in the case of laser-alloyed samples compared with that for as-received $\mathrm{Mg}$ alloy. It was proposed that $\mathrm{Al}_{12} \mathrm{Mg}_{17}$ is inert to chloride solutions and helps in the formation of passive film on the surface.

\section{Laser Composite Surfacing (LCS)}

In LCS, hard ceramic particles are introduced in the laser-melted surface of the substrate forming composite layer after subsequent resolidification. LCS can be performed either by powder injection in the melt or by preplacing the powder on the substrate followed by laser melting (Fig. 9). With the powder injection method, it is often difficult to reinforce fine (nanoscale) ceramic particles in the melt because of floating of the particle and agglomeration effects. Insufficient kinetic energy of the injected particle can cause agglomeration of the particles at the surface. However, a very high kinetic energy of the particle can move the melt away from the irradiated region. Even with the microscale particles, the maximum depth of particle penetration in the melt is often less than half of the maximum depth of melting. Relatively better uniformity of composite microstructure can be obtained by preplacing the powder followed by laser melting. Because of the large difference in the physical and thermal properties like density, melting point, and thermal conductivity of ceramic reinforcement and $\mathrm{Mg}$ substrate, it is essential to choose appropriate parameters to obtain uniform composite microstructure after solidification. Although partial
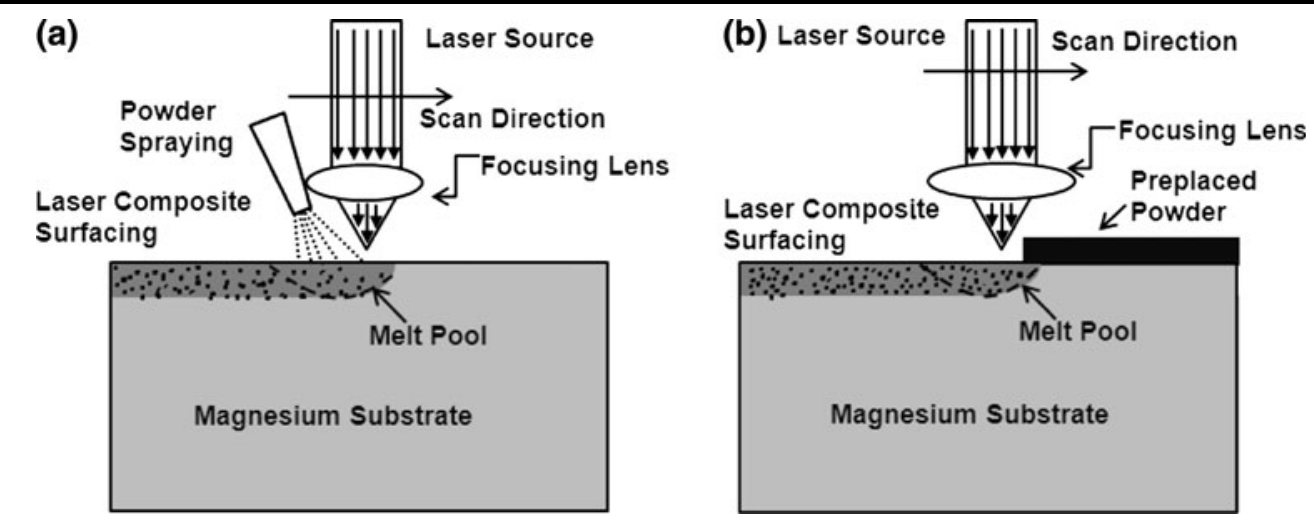

Fig. 9. Schematic of LCS: (a) direct powder injection and (b) preplacement of composite/ceramic powder using organic binder. 
surface melting of the ceramic particles may be unavoidable, it is important that ceramic particles are retained as second-phase particles in the matrix. The improvement in hardness/strength of the composite surface is primarily caused by second phase particle strengthening and grain refinement of the matrix. The properties depends on the secondphase particle size, percentage reinforcement, particle-matrix interface characteristics, matrix grain size, phases in the matrix, and the depth of composite layer. The undesirable interfacial reactions between reinforced particles and matrix need to be minimized, if not avoided.

\section{Microstructure Analysis}

LCS of MRI153 (7.95\%Al-0.98\%Ca-0.2\%Mn$0.27 \% \mathrm{Sr}$ ) alloy with preplaced $95 \% \mathrm{Al}_{2} \mathrm{O}_{3}$ (particle size: $10 \mu \mathrm{m}$ ) and $5 \% \mathrm{Al}$ (particle size: $10 \mu \mathrm{m}$ ) was reported by Samant et al. ${ }^{45} \mathrm{Al}$ was used to improve the wetting characteristic of $\mathrm{Al}_{2} \mathrm{O}_{3}$ particles in the melt. The different phases present on the laser composite surface were $\mathrm{Mg}, \mathrm{Al}_{2} \mathrm{O}_{3}, \mathrm{MgO}$, and $\mathrm{Al}_{0.9} \mathrm{Mg}_{3.1}$. It was also observed that the composite layer thickness decreased from $363 \mu \mathrm{m}$ to $224 \mu \mathrm{m}$ with an increase in scan speed because of a decrease in the laser material interaction time. A thermal model was used to predict the highest temperature attained during LCS. This temperature was higher than the melting point of $\mathrm{Al}_{2} \mathrm{O}_{3}$ in all processing conditions, resulting in melting and subsequent reformation of $\mathrm{Al}_{2} \mathrm{O}_{3}$ during solidification. However, the samples processed with $84 \mathrm{~mm} / \mathrm{s}$ (highest scan speed among investigated parameters) retained some primary $\mathrm{Al}_{2} \mathrm{O}_{3}$ particles along with the major portion of reconstituted (melted and resolidified) $\mathrm{Al}_{2} \mathrm{O}_{3}$ in the composite layer (Fig. 10). LCS of a Mg alloy $(93 \% \mathrm{Mg}$ $5.92 \% \mathrm{Al}-0.49 \% \mathrm{Zn}-0.15 \% \mathrm{Mn}-0.037 \% \mathrm{Si}-0.007 \% \mathrm{Fe}-$ $0.0613 \%$ others) reinforced with WC was studied by Dobrzanski et al. ${ }^{46}$ The powder was injected in the melt with an injection rate of $6 \mathrm{~g} / \mathrm{min}$. Uniform distribution of WC in the $\mathrm{Mg}$ matrix was reported in the study. Loss of $\mathrm{Zn}$ from matrix was also reported on laser melting because of the selective vaporization of $\mathrm{Zn}$ (Zn has relatively lower vapor pressure compared with $\mathrm{Mg}$ ). LCS of MEZ Mg alloy using SiC particles was reported by Majumdar et al. ${ }^{47}$ The laser power of $2 \mathrm{~kW}$, scan speed $200 \mathrm{~mm} / \mathrm{min}$, and $\mathrm{SiC}$ feed rate of $20 \mathrm{mg} / \mathrm{s}$ resulted in uniform distribution of $\mathrm{SiC}$ particles in the composite microstructure. It was found that particle penetration depth increased from $\sim 100 \mu \mathrm{m}$ to $\sim 420 \mu \mathrm{m}$ with an increase in laser power from $1 \mathrm{~kW}$ to $2.5 \mathrm{~kW}$ because of increased energy coupling at a higher power. The particle penetration depth decreased from $\sim 400 \mu \mathrm{m}$ to $\sim 300 \mu \mathrm{m}$ with an increase in scan speed from $100 \mathrm{~mm} / \mathrm{min}$ to $300 \mathrm{~mm} /$ min because of the reduction in interaction time. The total depth of melting for all the processing parameters was approximately three to four times the depth of particle penetration in composite layers. Majumdar et al. ${ }^{48}$ also investigated LCS of MEZ Mg alloy using $\mathrm{Cr}_{3} \mathrm{C}_{2}$ particles (injected into the melt with a feed rate of $16-30 \mathrm{mg} / \mathrm{s}$ ). Although a fair distribution of ceramic particles was observed in the
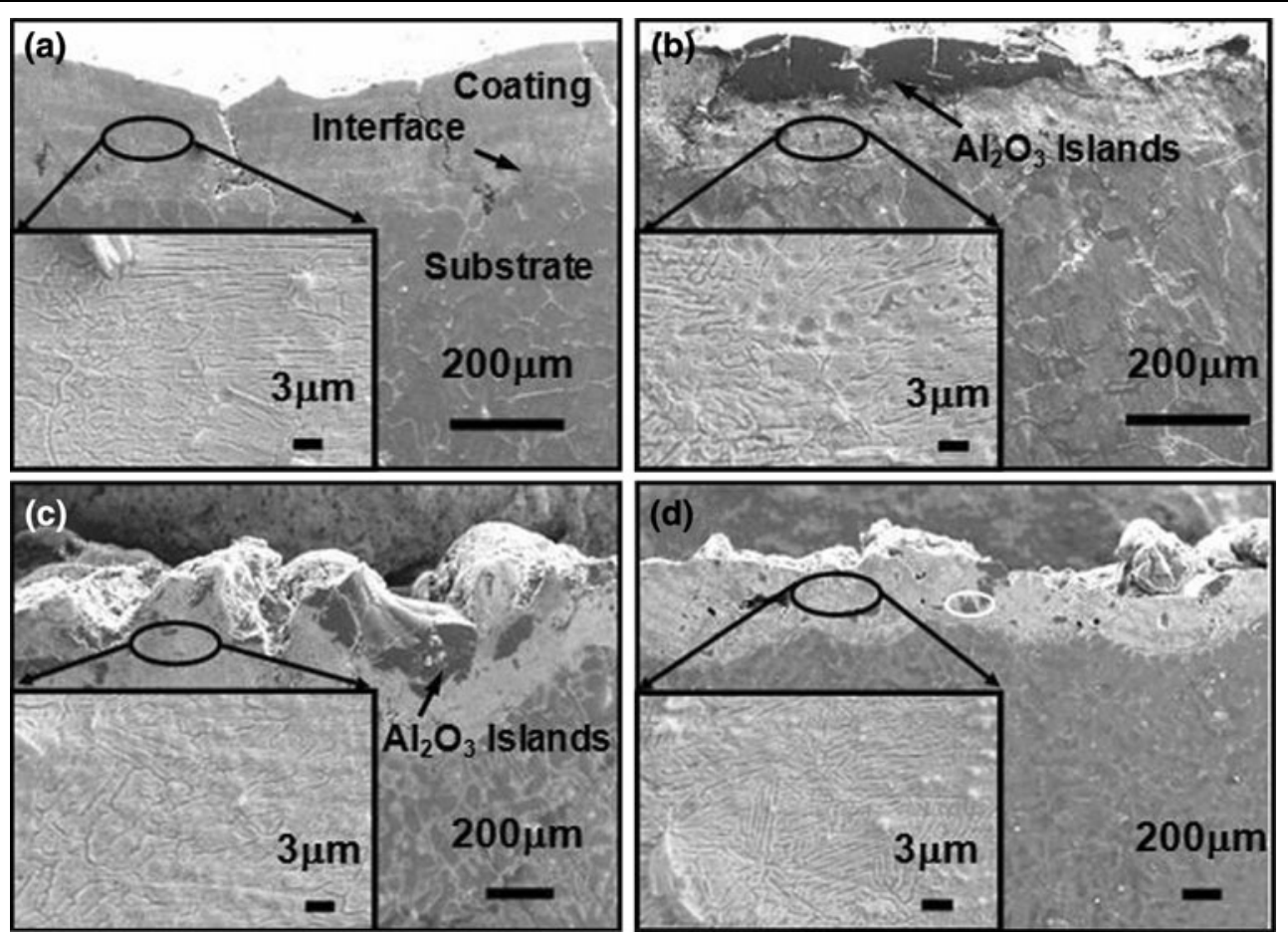

Fig. 10. Cross-sectional SEM images of a Mg alloy laser composite surfaced with $\mathrm{Al}_{2} \mathrm{O}_{3}$ using laser scan speeds of (a) $21 \mathrm{~mm} / \mathrm{s}$, (b) $42 \mathrm{~mm} / \mathrm{s}$, (c) $63 \mathrm{~mm} / \mathrm{s}$, and (d) $84 \mathrm{~mm} / \mathrm{s}$ (Inset: high-magnification image showing the secondary dendrites) ${ }^{45}$ (Reprinted with permission from Elsevier). 
Table III. List of various Mg alloys laser composite surfaced with different materials, associated laser processing parameters, and observed layer thickness and hardness

\begin{tabular}{|c|c|c|c|c|c|c|c|}
\hline Laser & Substrate & $\begin{array}{c}\text { Composite } \\
\text { materials }\end{array}$ & $\begin{array}{c}\text { Laser } \\
\text { power }(\mathbf{k W})\end{array}$ & $\begin{array}{c}\text { Spot } \\
\text { size }(\mathbf{m m})\end{array}$ & $\begin{array}{c}\text { Scan } \\
\text { speed }(\mathbf{m m} / \mathbf{s})\end{array}$ & $\begin{array}{c}\text { Layer } \\
\text { thickness }(\mu \mathrm{m})\end{array}$ & $\begin{array}{c}\text { Hardness } \\
\text { (HV) }\end{array}$ \\
\hline Nd:YAG & MRI $153 \mathrm{M}^{64}$ & $\mathrm{Al}+\mathrm{Al}_{2} \mathrm{O}_{3}$ & - & 0.5 & $21-84$ & - & 90 \\
\hline HPDL & MCMgAl6Zn $1^{49}$ & WC-SiC & 1.6 & $1.8 \times 6.8$ & $8.3-16.6$ & 400 & 250 \\
\hline HPDL & MCMgAl6Zn $1^{46}$ & WC & 1.6 & $1.8 \times 6.8$ & $8.3-16.6$ & 400 & 250 \\
\hline $\mathrm{CO}_{2}$ & $\mathrm{MEZ}^{47}$ & $\mathrm{SiC}$ & $1-4.5$ & 4 & $1.6-6.6$ & 1,600 & 250 \\
\hline $\mathrm{CO}_{2}$ & $\mathrm{MEZ}^{62}$ & $\mathrm{Al}+\mathrm{Al}_{2} \mathrm{O}_{3}$ & $1.5-4$ & 4 & $1.66-16.6$ & 900 & 350 \\
\hline $\mathrm{CO}_{2}$ & $\mathrm{MEZ}^{48}$ & $\mathrm{Cr}_{3} \mathrm{C}_{2}$ & $1-4.5$ & 4 & $1.66-13.3$ & 1,500 & 160 \\
\hline
\end{tabular}

composite layer, some agglomeration near the surface was observed mainly because of the higher cooling rates at the surface. The thickness of the laser composite layer and the fractional area of $\mathrm{Cr}_{3} \mathrm{C}_{2}$ can be effectively controlled by optimizing the laser power and scan speed. Table III provides the summary of $\mathrm{Mg}$ alloys laser composite surfaced with different hard particles, as well as corresponding processing parameters and properties (hardness and composite layer thickness).

\section{Hardness and Wear Resistance}

The variation in microhardness along the cross section of laser composite surfaced MRI153 Mg alloy using $\mathrm{Al}$ and $\mathrm{Al}_{2} \mathrm{O}_{3}$ was investigated. ${ }^{45}$ The microhardness of the surface increased from $70 \mathrm{HV}$ to $130 \mathrm{HV}$ after LCS. A gradual decrease in microhardness from the laser composite surface toward the substrate was observed. The increase in microhardness was mainly caused by the refined microstructure of $\mathrm{Mg}$ and the presence of alumina particulates uniformly distributed in the composite surface region. LCS of EN-MCMgAl6Zn1 with WC and $\mathrm{TiC}$ also resulted in an increase in microhardness from $70 \mathrm{HV}$ to $250 \mathrm{HV}{ }^{49}$ Fluctuations in the microhardness in the laser composite zone were observed mainly because of the random distribution of reinforced particulates. Majumdar et al. ${ }^{47}$ also observed that an increase in laser power resulted in a decrease in microhardness of the laser composite surface (Fig. 11). At a higher laser power, the melting depth and penetration depth of the particles was higher, resulting in a lower volume fraction of $\mathrm{SiC}$ particles at the surface. An increase in laser scan speed resulted in an initial increase in microhardness because of the grain refinement associated with higher cooling rates. A subsequent increase in laser speed resulted in a decrease in microhardness because of the decrease in particle fractional area. Similar studies were also reported for LCS of MEZ with $\mathrm{Cr}_{3} \mathrm{C}_{2}$ by Majumdar et al. ${ }^{48}$ The optimization of laser processing parameters is important to achieve excellent wear behavior. Samant et al. ${ }^{45}$ investigated the wear response of an MRI $153 \mathrm{M} \mathrm{Mg}$ alloy laser composite surfaced with $\mathrm{Al}$ and $\mathrm{Al}_{2} \mathrm{O}_{3}$. It was shown that the laser power and scan speed are important parameters influ-
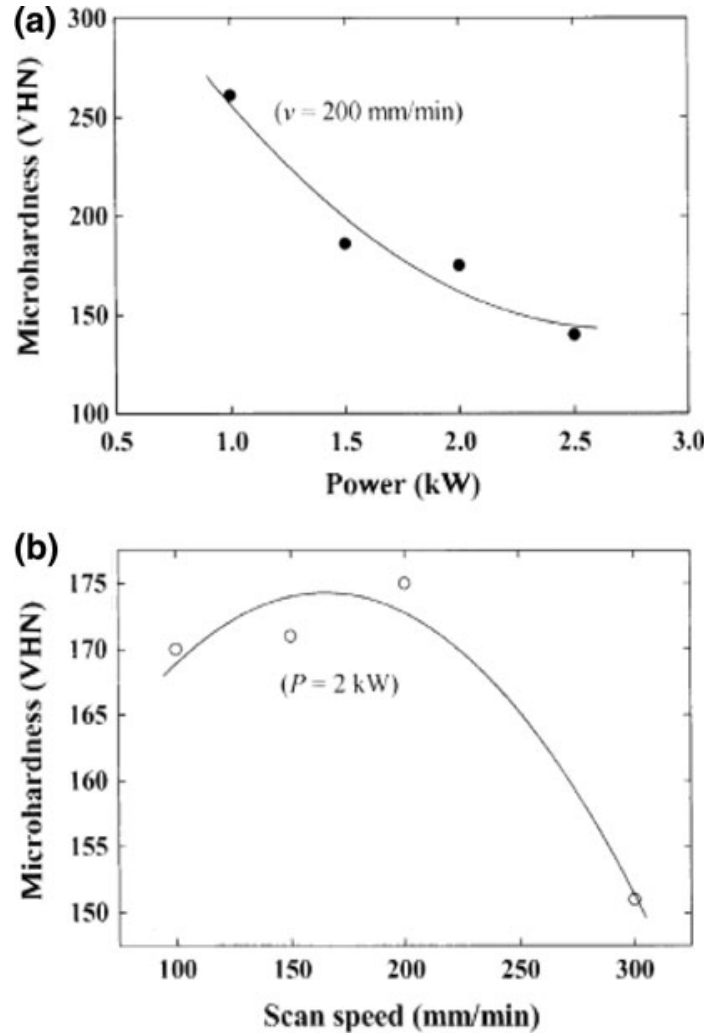

Fig. 11. Variation of the average surface microhardness of MEZ alloy laser composite surfaced using $\mathrm{SiC}$ with (a) laser power (at a scan speed of $200 \mathrm{~mm} / \mathrm{min}$, powder feed rate of $20 \mathrm{mg} / \mathrm{s}$ ), and (b) laser scan speed (at a laser power of $2 \mathrm{~kW}$, powder feed rate of $20 \mathrm{mg} / \mathrm{s})^{47}$ (Reprinted with permission from Elsevier).

encing the cooling rate during resolidification of composite layer. LCS with laser scan speed of $42 \mathrm{~mm} / \mathrm{s}$ resulted in the highest wear resistance compared to that with laser scan speeds of $84 \mathrm{~mm} / \mathrm{s}$ and $21 \mathrm{~mm} / \mathrm{s}$. The laser scan speed of $21 \mathrm{~mm} / \mathrm{s}$ was associated with lowest cooling rate resulting in the formation of coarse grains. Hence, a high wear rate was observed for the samples processed with this laser scan speed. LCS of MEZ Mg alloy with $\mathrm{SiC}$ resulted in an increase in wear resistance of the surface. This was mainly because of the increase in microhardness with the presence of $\mathrm{SiC}$ and refinement of microstructure as a result of laser treatment. 
(a)

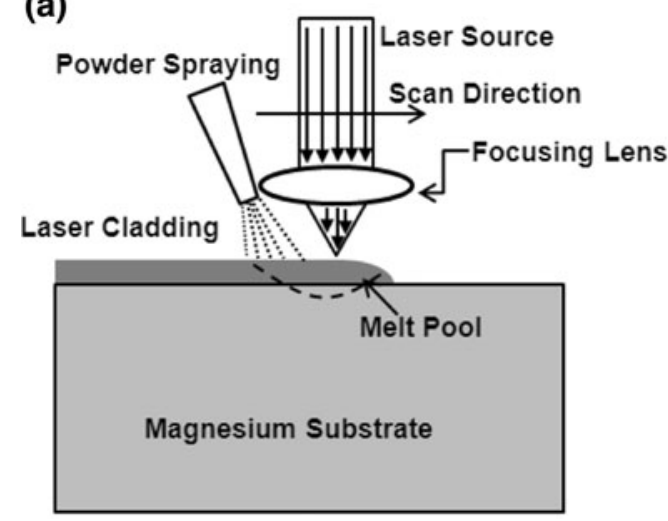

(b)

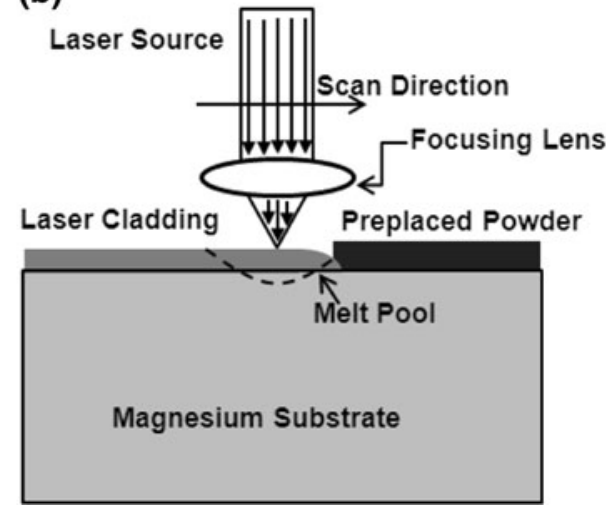

Fig. 12. Schematic of LSC: (a) direct powder injection and (b) preplacement of cladding powder using organic binder.

\section{Laser Surface Cladding (LSC)}

In LSC, a relatively thick layer (generally thicker than $500 \mu \mathrm{m}$ ) of a chemically different material is bonded/fused on the surface of the substrate. The process involves laser melting of the material to be clad on the substrate without significant dilution from the substrate. A schematic of the LSC process is shown in Fig. 12. However, some reactions/mixing in the interfacial region become important to achieve good bonding of the clad layer to the substrate. The rapid solidification of the cladding material can result in grain refinement, the extension of solid solubility, and the formation of nonequilibrium phases in the clad layer without significant changes in the microstructure of the substrate. ${ }^{50}$ In most cases, LSC is accomplished by preplacing desired material (in the form of slurry, loose powder, and spray dried coating) on the substrate followed by LSM. The process can be used for cladding a variety of materials, including metal/alloys, ceramics, composite, or amorphous alloys, on the substrates. Although the process has been used extensively for repairing of components, the process also presents tremendous potential for producing protective surfaces. ${ }^{26,51,52}$ Considering the issues related to wear and corrosion of $\mathrm{Mg}$ alloys, LSC is also attractive for improving the surface properties of these alloys.

\section{Microstructure Analysis}

Recently, LSC of Zr-based metallic glass (composition $\mathrm{Zr}_{65} \mathrm{Al}_{7.5} \mathrm{Ni}_{10} \mathrm{Cu}_{17.5}$; clad thickness of $1.5 \mathrm{~mm}$ ) on $\mathrm{Mg}$ substrate was investigated by Yue et al. ${ }^{53} \mathrm{High}$ cooling rates obtained in LSC helped in retaining the amorphous structure of the alloy. There was no indication of presence of $\mathrm{Mg}$ in the clad zone, which was crucial for the formation of the amorphous phase. A multilayer, 3-mm-thick amorphous laser cladding was also processed by Yue and $\mathrm{Su} .{ }^{54} \mathrm{~A}$ phase analysis along the cross section of the clad layer indicated fully amorphous phase on the top surface of the cladding. However, partial crystallization with precipitate size

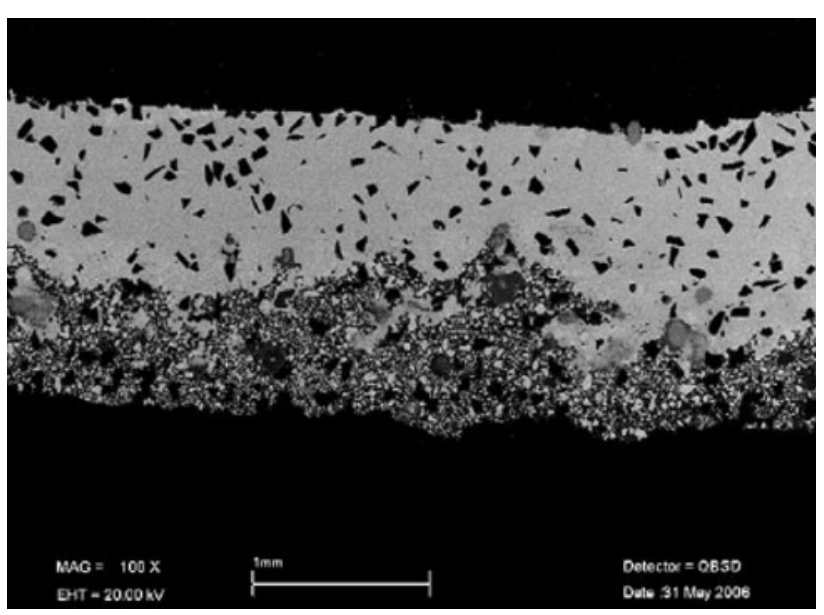

Fig. 13. A SEM micrograph showing a transverse cross-section of the $\mathrm{Mg}$ substrate laser clad with $\mathrm{SiC}$ reinforced $\mathrm{Zr}$-based amorphous alloy $^{55}$ (Reprinted with permission from Elsevier).

of approximately $30 \mathrm{~nm}$ was observed in the middle region of the clad section. At the bottom region of the clad region (near interface), crystallites of hexagonal $\mathrm{hP}-\mathrm{Zr}_{65.4} \mathrm{Al}_{11.7} \mathrm{Ni}_{11.6} \mathrm{Cu}_{11.3}$ and body-centered tetragonal tI- $\mathrm{Zr}_{67.0} \mathrm{Al}_{1.7} \mathrm{Ni}_{8.4} \mathrm{Cu}_{22.9}$ were observed. In other experiments, LSC of SiC-reinforced Zr-based metallic glass (with the composition $\mathrm{Zr}_{65} \mathrm{Al}_{7.5} \mathrm{Ni}_{10}$ $\mathrm{Cu}_{17.5}$ ) was performed (Fig. 13). ${ }^{55}$ Laser cladding of $\mathrm{Zr}$-based amorphous alloy reinforced with $\mathrm{SiC}$ resulted in the formation of a new $\mathrm{ZrC}$ phase. The amorphous nature of the clad was observed despite the formation of a new phase during laser cladding. Differential scanning calorimetry results also indicated that reinforcement of SiC particles did not influence the thermal stability of the alloy and that the amorphous structure of the alloy was retained in the clad layer. LSC of functionally graded $\mathrm{Ni} / \mathrm{Cu} / \mathrm{Al}$ on $\mathrm{Mg}$ substrate was investigated by Yue and $\mathrm{Li}^{56}$ The deposition of metal layers on the $\mathrm{Mg}$ substrate followed the sequence of $\mathrm{Al}, \mathrm{Cu}$, and then $\mathrm{Ni}$. The total thickness of the clad region was approximately $2,000 \mu \mathrm{m}$, where the thickness of the Ni layer was approximately $500 \mu \mathrm{m}$ and the thickness of the $\mathrm{Cu}$ 
layer was approximately $1,000 \mu \mathrm{m}$. No cracks or voids were spotted among the layers of $\mathrm{Ni}-\mathrm{Cu}, \mathrm{Cu}-\mathrm{Al}$, and $\mathrm{Al}-\mathrm{Mg}$ after cladding, indicating good bonding between the clad layers. The top layer of $\mathrm{Ni}$ was free from any other elements, but the presence of $\mathrm{Ni}$ was observed in both $\mathrm{Cu}$ and $\mathrm{Al}$ layers. The presence of $\mathrm{Mg}$ was also observed in the aluminum layer. LSC of AZ91D Mg alloy with $\mathrm{Al}+\mathrm{Si}+\mathrm{Al}_{2} \mathrm{O}_{3}$ was also studied by Jun et al ${ }^{57}$ Laser power between $0.5 \mathrm{~kW}$ and $5 \mathrm{~kW}$ and a scan speed between $3 \mathrm{~mm} / \mathrm{s}$ and $28 \mathrm{~mm} / \mathrm{s}$ were used in this investigation. The presence of $\mathrm{Al}$ with $\mathrm{Si}$ and $\mathrm{Al}_{2} \mathrm{O}_{3}$ enhanced the corrosion resistance of the surface. A significant variation was found in the width of the clad $(720-920 \mu \mathrm{m})$ and volume fraction of $\mathrm{Al}, \mathrm{Si}$, and $\mathrm{Al}_{2} \mathrm{O}_{3}(1-10 \%)$ when laser scan speed and laser power were varied. The depth of the clad layer decreased with an increase in the laser scan speed because of the shorter laser-material interaction time at higher speeds. The clad width increased with an increase in the laser power as more energy was absorbed by the material. It should be noted that finding the optimum parameters is important to obtain outstanding clad surface properties. A high laser power or too low scan speed can lead to surface evaporation of $\mathrm{Mg}$ and crater formation. In contrast, a very low laser power or high scan speed can cause nonuniform distribution of $\mathrm{Si}$ and $\mathrm{Al}_{2} \mathrm{O}_{3}$ particles on the surface because of poor melting and inadequate intermixing. Liu et al. ${ }^{58}$ performed LSC of AZ91D Mg alloy with $\mathrm{Al}$ and $\mathrm{Al}_{2} \mathrm{O}_{3}$. $\mathrm{Al}$ was mixed with $\mathrm{Al}_{2} \mathrm{O}_{3}$ (mixed in the ratio of $2: 1,3: 1$, and $4: 1)$ to enhance the corrosion resistance. The laserclad microstructure consisted of refined $\alpha-\mathrm{Mg}$, $\mathrm{Al}_{12} \mathrm{Mg}_{17}$, and $\mathrm{Al}_{2} \mathrm{O}_{3}$ particles uniformly distributed throughout the surface. The volume fraction of $\mathrm{Al}_{12} \mathrm{Mg}_{17}$ for the samples with $\mathrm{Al}$ to $\mathrm{Al}_{2} \mathrm{O}_{3}$ ratios of $2: 1,3: 1$, and $4: 1$ was calculated to be $19.3,15.2$, and 10.6, respectively. Hence, a decrease in $\mathrm{Al}$ content resulted in a decrease in the volume fraction of $\mathrm{Al}_{12} \mathrm{Mg}_{17}$. LSC on AZ91HP was also done using $\mathrm{Al}$ (33 wt.\%)-Cu alloy to enhance the corrosion resistance of the surface. ${ }^{59}$ The microstructure of the surface clad showed three different regions: clad region, bonding zone, and heat-affected zone. The intermetallics $\mathrm{AlCu}_{4}, \mathrm{Mg}_{17} \mathrm{Al}_{12}$, and $\mathrm{AlMg}$ were formed in the clad zone. LSC of ZE41 with Al-Si was studied by Volovitch et al. ${ }^{60}$ In this study, three different consecutive passes with overlapping zones were created with scan speed of $300 \mathrm{~mm} / \mathrm{min}$, $400 \mathrm{~mm} / \mathrm{min}$, and $500 \mathrm{~mm} / \mathrm{min}$. The different phases formed in the cladded surface were $\mathrm{Al}, \mathrm{Mg}, \mathrm{Mg}_{17} \mathrm{Al}_{12}$, and $\mathrm{Mg}_{2} \mathrm{Si}$. The first clad layer (scan speed $300 \mathrm{~mm} /$ min) was nonuniform and it consisted mainly of varying concentration of $\mathrm{Al}$ throughout the layer. Intermetallics like $\mathrm{Mg}_{17} \mathrm{Al}_{12}$ and $\mathrm{Mg}_{2} \mathrm{Si}$ were formed only at the interface between the first and second layer. The second clad layer (scan speed 400 $\mathrm{mm} / \mathrm{min}$ ) mainly consisted of $\mathrm{Al}$ and phases like $\mathrm{Al}-$ $\mathrm{Mg}, \mathrm{Al}_{8} \mathrm{Mg}_{5}, \mathrm{Mg}_{17} \mathrm{Al}_{12}$, and $\mathrm{Mg}_{2} \mathrm{Si}$. In the third clad layers (scan speed $500 \mathrm{~mm} / \mathrm{min}$ ), phases like $\mathrm{Mg}_{17} \mathrm{Al}_{12}$ and $\mathrm{Al}$ were found. Bronfin et al. ${ }^{61}$ performed a parametric study on LSC of AS21 (1.9-2.5\%Al$0.15-0.2 \% \mathrm{Zn}-0.35 \% \mathrm{Mn}-0.7-1.2 \% \mathrm{Si}-0.04 \% \mathrm{Cu}-$ $0.002 \% \mathrm{Ni}$ ) with $\mathrm{Al} / \mathrm{Si}(41$ wt.\%) and WC (60 wt.\%) powder. At a higher scan speed, clad thickness and clad width both decreased. The distribution of WC particles in the coated zone also depends on melt pool convection currents and solidification time. Majumdar et al. ${ }^{62}$ performed LSC on MEZ using $\mathrm{Al}$ and $\mathrm{Al}_{2} \mathrm{O}_{3}$ in the ratio of $3: 1$. In this process, Al was alloyed with $\mathrm{Mg}$ matrix and $\mathrm{Al}_{2} \mathrm{O}_{3}$ particles were distributed throughout the matrix. The alloyed zone mostly consisted of $\mathrm{Mg}_{17} \mathrm{Al}_{12}$ and $\mathrm{Mg}$. In addition, the composite microstructure of the alloyed zone changed from hypoeutectic to hypereutectic depending on the process parameters and concentration of $\mathrm{Al}$ and $\mathrm{Al}_{2} \mathrm{O}_{3}$. A complete parametric study was performed, and a variation of surface width was shown with laser power and scan speed. As fractional area of particles is a significant factor determining the mechanical properties of clad surface; the variation of fractional area of the particles with laser power and scan speed was studied in detail. It was found that an increase in incident laser power resulted in a decrease in the volume fraction of the particle. The fractional area of the particle also decreased with an increase in laser scan speed. To improve the surface properties of ZK60/SiC composite, Al-Si eutectic alloy was clad using Nd:YAG laser by Yue et al. ${ }^{63} \mathrm{Al}-\mathrm{Si}$ eutectic alloy was compatible for LSC on ZK60/SiC composite because of a very small difference in their melting points $\left(515^{\circ} \mathrm{C}\right.$ for substrate and $575^{\circ} \mathrm{C}$ for $\mathrm{Al}$-Si alloy). Good interfacial bonding between base metal and clad surface was observed. Recently, Hazra et al. ${ }^{64}$ performed LSC of MRI153 Mg alloy with $\mathrm{Al}_{2} \mathrm{O}_{3}$ and $\mathrm{Al}$. The different phases formed after laser cladding were $\alpha-\mathrm{Mg}, \mathrm{Al}_{2} \mathrm{O}_{3}, \mathrm{Al}_{0.9} \mathrm{Mg}_{3.1}$, and $\mathrm{MgO}$. It was found that an increase in laser scan speed resulted in a decrease in the melting zone. These depths of melting with different scan speeds can be predicted using temperature distribution profiles. Table IV provides a summary of laser cladding of various $\mathrm{Mg}$ alloys with different materials, associated laser processing parameters, and observed layer thickness and hardness.

\section{Hardness and Wear Resistance}

Yue et al. $^{56}$ investigated variation of hardness along the cross section of laser-clad Ni/Cu/Al graded composite on $\mathrm{Mg}$ substrate. The hardness of the laser-clad surface was approximately $150 \mathrm{HV}$, whereas the hardness of the substrate was $\sim 50 \mathrm{HV}$. A very high hardness of $700 \mathrm{HV}$ was observed at a distance of $1,500 \mu \mathrm{m}$ from the clad surface (Fig. 14). This increase in hardness was caused by the formation of $\gamma 1, \lambda 1$, and $\lambda 2$ phases, where $\lambda 1$ and $\lambda 2$ are Mg-based ternary Laves-Friauf phases and the $\gamma 1$ phase consists of structure that is similar to $\mathrm{Cu}_{9} \mathrm{Al}_{4}$. LSC of $\mathrm{Zr}_{65} \mathrm{Al}_{7.5} \mathrm{Ni}_{10} \mathrm{Cu}_{17.5}$ amorphous alloy resulted in consistent microhardness of 550-600 HV up to a thickness of $1.1 \mathrm{~mm} .^{53}$ The microhardness of laser 
Table IV. List of various Mg alloys laser clad with different materials, associated laser processing parameters, and observed clad thickness and hardness

\begin{tabular}{|c|c|c|c|c|c|c|c|}
\hline Laser & Substrate & $\begin{array}{l}\text { Cladding } \\
\text { materials }\end{array}$ & $\begin{array}{c}\text { Laser } \\
\text { power }(\mathbf{k W})\end{array}$ & $\begin{array}{c}\text { Spot } \\
\text { size }(\mathbf{m m})\end{array}$ & $\begin{array}{c}\text { Scan } \\
\text { speed }(\mathbf{m m} / \mathbf{s})\end{array}$ & $\begin{array}{c}\text { Clad } \\
\text { thickness }(\mu \mathrm{m})\end{array}$ & $\begin{array}{c}\text { Hardness } \\
\text { (HV) }\end{array}$ \\
\hline $\mathrm{CO}_{2}$ & AZ91HP ${ }^{59}$ & $\mathrm{Al}-\mathrm{Cu}$ & 2.5 & $10 \times 1$ & 5 & 900 & 350 \\
\hline Nd:YAG & $\mathrm{AZ91D}^{58}$ & $\mathrm{Al}-\mathrm{Al}_{2} \mathrm{O}_{3}$ & $0.5-3$ & 3 & $3-28$ & 800 & - \\
\hline Nd:YAG & $\mathrm{AZ} 91 \mathrm{D}^{67}$ & $\mathrm{Al}-\mathrm{Si}$ & - & 0.5 & $0.5-2.5$ & 900 & 170 \\
\hline Nd:YAG & AZ91D & $\mathrm{Al}-\mathrm{Al}_{2} \mathrm{O}_{3}$ & - & 0.5 & $0.5-2.5$ & 1,100 & 210 \\
\hline Nd:YAG & $\mathrm{AZ} 91 \mathrm{D}^{57}$ & $\mathrm{Al}-\mathrm{Si}-\mathrm{Al}_{2} \mathrm{O}_{3}$ & $0.5-5$ & 3 & $3-28$ & 2,500 & 210 \\
\hline Nd:YAG & $\mathrm{AS} 21^{61}$ & Al-Si, WC & $1.4-1.6$ & - & $3.33-8.33$ & 2,000 & - \\
\hline Nd:YAG & $\mathrm{ZK} 60 / \mathrm{SiC}^{69}$ & Stainless steel & $0.5-1.5$ & 2 & $5-12$ & 500 & - \\
\hline Nd:YAG & $\mathrm{ZE} 41^{60}$ & $\mathrm{Al}-\mathrm{Si}$ & 1.5 & 4 & $5-8.33$ & 500 & 173 \\
\hline $\mathrm{CO}_{2}$ & $\mathrm{AZ91HP} \mathrm{H}^{65}$ & $\mathrm{Al}_{2} \mathrm{O}_{3}$ & $1-1.2$ & $10 \times 1$ & $5-11.66$ & & 1,530 \\
\hline $\mathrm{CO}_{2}$ & $\mathrm{Mg}^{56}$ & $\mathrm{Ni} / \mathrm{Cu} / \mathrm{Al}$ & $1.4-2$ & - & 5 & 2,000 & 160 \\
\hline $\mathrm{CO}_{2}$ & $\mathrm{Mg}_{55}^{53}$ & $\mathrm{Zr}_{65} \mathrm{Al}_{7.5} \mathrm{Ni}_{10} \mathrm{Cu}_{17.5}$ & 3.7 & 1 & 5 & 1,500 & $550-600$ \\
\hline $\mathrm{CO}_{2}$ & $\mathrm{Mg}^{55}$ & $\mathrm{Zr}_{65} \mathrm{Al}_{7.5} \mathrm{Ni}_{10} \mathrm{Cu}_{17.5}-\mathrm{SiC}$ & 4.2 & 1 & 5 & 1,800 & $1,000-1,100$ \\
\hline
\end{tabular}

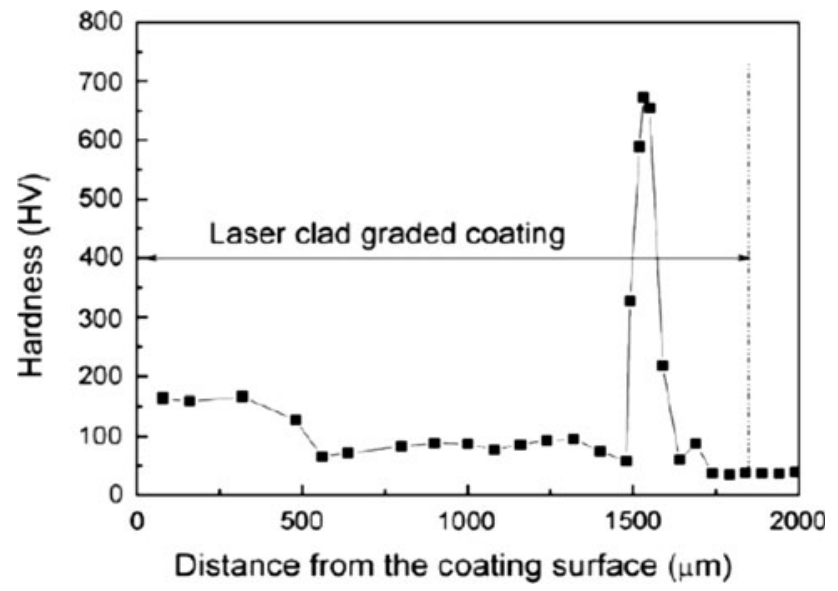

Fig. 14. Microhardness profile across the Ni/Cu/Al graded cladding on $\mathrm{Mg}$ substrate ${ }^{56}$ (Reprinted with permission from Elsevier).

multilayer cladding of $\mathrm{Zr}_{65} \mathrm{Al}_{7.5} \mathrm{Ni}_{10} \mathrm{Cu}_{17.5}$ was also investigated by Yue and Su. ${ }^{54}$ It was observed that the microhardness of the cladding surface was $550 \mathrm{HV}$ up to $1,250 \mu \mathrm{m}$ and then it increased sharply to $800 \mathrm{HV}$ between $1,250 \mu \mathrm{m}$ and $2,000 \mu \mathrm{m}$ from the surface because of the formation of a nanocrystalline phase in the amorphous matrix. At a deeper region in the cross section $(2,000-3,000 \mu \mathrm{m}$ from the surface), a decrease in microhardness to 450 $500 \mathrm{HV}$ was observed because of the coarsening of the crystallized nanoparticles. The hardness of SiCreinforced Zr-based amorphous alloy laser clad on $\mathrm{Mg}$ substrate was also investigated by Yue and $\mathrm{Su}{ }^{55}$ The hardness of the composite amorphous clad surface was $694 \mathrm{HV}$, which was higher than the unreinforced amorphous clad (555 HV). The hardness $(\sim 1,150 \mathrm{HV})$ at the interface was higher than that in other clad regions ( $\sim 950 \mathrm{HV}$ to $1,050 \mathrm{HV})$, indicating the presence of a reacted zone and the formation of harder phases like $\mathrm{ZrC}$. The nanohardness of laser-clad $\mathrm{Al}_{2} \mathrm{O}_{3}$ on AZ91HP was compared with that obtained with other cladding techniques like plasma spraying and sintering. ${ }^{65}$ It was observed that the maximum hardness obtained with laser cladding ( $16 \mathrm{GPa})$ was significantly higher than that obtained with plasma spraying $(\sim 10 \mathrm{GPa})$ and sintering (12 GPa).

The wear resistance of AZ91HP $\mathrm{Mg}$ alloy was found to be increased by approximately nine times after laser cladding it with $\mathrm{Al}-\mathrm{Cu}$ alloy. ${ }^{59}$ The increase in wear resistance was mainly the result of the formation of $\mathrm{AlCu}_{4}$. LSC of AZ91D with $\mathrm{Al}$ and $\mathrm{Al}_{2} \mathrm{O}_{3}$ also resulted in an increase in wear resistance as indicated by a decreased wear volume loss. ${ }^{58}$ The clad obtained with an $\mathrm{Al}$ to $\mathrm{Al}_{2} \mathrm{O}_{3}$ ratio of 3:1 showed better wear resistance than that with ratios of $2: 1$ and 4:1. The higher amount of $\mathrm{Al}$ content led to a better flowing property, resulting in a higher percentage of $\mathrm{Al}_{2} \mathrm{O}_{3}$ in the clad. The effect of LSC on the wear behavior of ZE41 was investigated by Fabre and Masse. ${ }^{66}$ It was observed that the wear behavior of the as-received ZE41 and laser-clad ZE41 was similar for the first 200 cycles. Thereafter, the wear loss increased significantly on the as-received ZE41. LSC of AZ91D with Al-Si powder resulted in an increase in wear resistance because of the formation of distributed phases like $\mathrm{Mg}_{2} \mathrm{Si}$ and $\mathrm{Mg}_{17} \mathrm{Al}_{12} .{ }^{67}$ The effect of Si content on wear resistance of Al-Si clad AZ91D alloy was also investigated. It was observed that the Si content of 12.5 wt.\% resulted in the best wear resistance (Fig. 15).

\section{Corrosion Resistance}

Electrochemical studies on the $\mathrm{Ni} / \mathrm{Cu} / \mathrm{Al}$ clad $\mathrm{Mg}$ alloy showed that there was significant improvement in corrosion resistance of the clad region. The laser-clad specimen showed passivity at $500 \mathrm{mV}$, whereas the $\mathrm{Mg}$ substrate showed no sign of passivity. The top Ni layer present in the clad seems to form protective passive film under corrosion. ${ }^{56} \mathrm{Hu}-$ ang et al. ${ }^{68}$ studied laser cladding of amorphous copper alloy and amorphous copper reinforced with $20 \% \mathrm{SiC}$ on AZ91D Mg alloy. The corrosion resis- 


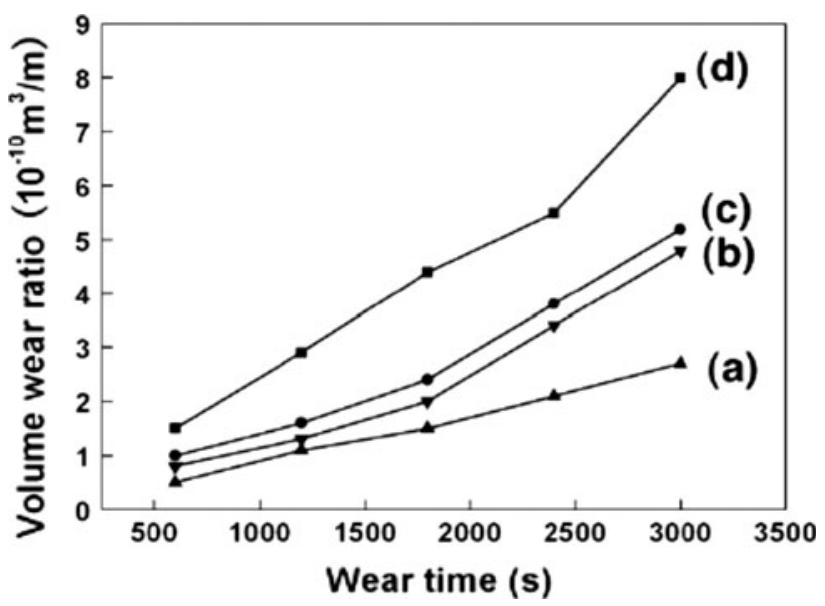

Fig. 15. Effect of Si content on volume wear loss of Al-Si clad AZ91D alloy: (a) 12.5 wt.\% Si, (b) $60 \mathrm{wt.} \% \mathrm{Si}$, (c) 8 wt.\% Si, and (d) as-received $\mathrm{Mg}$ alloy (all under the condition of scanning speed of $1.5 \mathrm{~mm} / \mathrm{s}$ and power density of $\left.0.783 \times 10^{9} \mathrm{~W} / \mathrm{m}^{2}\right)^{67}$ (Reprinted with permission from Elsevier).

tance of monolithic amorphous cladding was higher than that for the $\mathrm{SiC}$ reinforced $\mathrm{Cu}$-based amorphous alloy mainly because of the presence of a higher volume fraction of $\mathrm{Cu}$-based amorphous alloy with excellent corrosion-resistance properties. LSC of $\mathrm{Al}-\mathrm{Cu}$ on AZ91HP resulted in the enhancement of corrosion resistance. ${ }^{59}$ The as-received $\mathrm{Mg}$ alloy was corroded because of the formation of galvanic couples between $\alpha-\mathrm{Mg}$ and $\beta-\mathrm{Mg}_{17} \mathrm{Al}_{12}$. The presence of $\mathrm{Al}_{2} \mathrm{O}_{3}$ film on the laser-clad surface acted as a protective layer. The refinement of grains decreases the active cathode-anode area of the galvanic couples thereby decreasing the corrosion current. Mei and Yue $^{69}$ also investigated the corrosion behavior of laser-clad steel on ZK60/SiC composite and compared it with thermal sprayed steel coatings on ZK60/SiC. The laser-clad sample showed higher corrosion potential and lower corrosion current indicating an increase in corrosion resistance. No passive layer was formed on the as-received and thermally sprayed coatings. In the case of laser-clad samples, the presence of copper at the interdendritic spacing resulted in a galvanic attack on the surface and the formation of a discontinued passive layer. Hence, it is important to evaluate the possibility of the formation of a galvanic cell while choosing materials for cladding or alloying. A comparative study on the corrosion behavior for plasma-sprayed and laser-clad $\mathrm{Al}_{2} \mathrm{O}_{3}$ on AZ91HP was performed by Gao et al. ${ }^{65}$ The corrosion current for laser-clad surface was three orders of magnitude lower because of the high density and absence of porosity. Three stages of corrosion mechanisms for laser-clad ZE41 with Al-Si powder were proposed by Volovitch et al. ${ }^{60}$ In the first stage, partial dissolution of $\mathrm{Mg}_{2} \mathrm{Si}$ particles with the formation of crevices occurs. The removal of $\mathrm{Mg}_{2} \mathrm{Si}$ particles is accompanied by the formation of oxides and a hydroxide layer. After

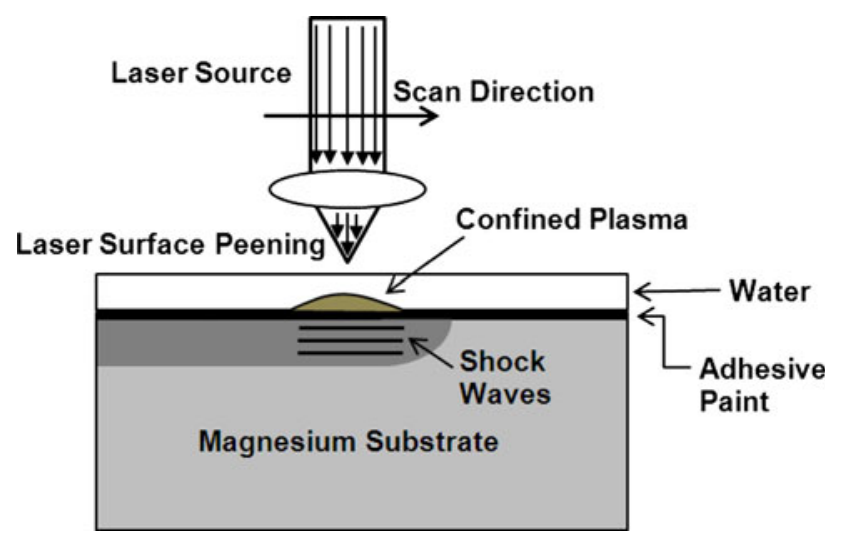

Fig. 16. Schematic of LSP process.

complete dissolution of $\mathrm{Mg}_{2} \mathrm{Si}$ particles, the second stage involves pitting corrosion of the matrix in the presence of a second phase. The third and final stage is complete matrix dissolution.

\section{Laser Shock Peening (LSP)}

When a material is irradiated with a very high power $\left(>10^{9} \mathrm{~W} / \mathrm{cm}^{2}\right)$ and short-pulse (1-50 ns) laser, the laser-materials interaction at the surface results in the generation of plasma. In LSP, the substrate is often covered with thin insulating or absorbing layer, which can be paint, metal, or plastic tape (Fig. 16). A transparent material (commonly water) is then placed over the absorbing layer. When the high-intensity laser beam is irradiated on the surface, it is absorbed by the absorbing layer on the substrate forming plasma. The plasma confined by the transparent materials then induces shock waves in the substrate. The shock waves can cause plastic deformation at the surface and introduce compressive residual stresses. LSP has been used for improving fatigues life of light alloys. LSP offers advantages such as a higher depth of plastic deformation (than conventional shot peening) and a minimum effect on surface roughness of the substrate. ${ }^{70-72}$ LSP has also been used to enhance the surface properties like wear and corrosion resistance of $\mathrm{Mg}$ alloys.

Chen et al. ${ }^{73}$ investigated the effect of LSP on pitting corrosion behavior of AM50 (4.83\%Al$0.32 \% \mathrm{Mn}) \mathrm{Mg}$ alloys. A Q-switched Nd:Glass laser with wavelength of $1,054 \mathrm{~nm}$, laser power of $3 \mathrm{GW} /$ $\mathrm{cm}^{2}$, pulse width of $23 \mathrm{~ns}$, pulse repetition rate of $0.5 \mathrm{~Hz}$, and spot diameter of $5 \mathrm{~mm}$ was used for laser peening of $\mathrm{Mg}$ alloy substrate covered with black paint as an absorbing layer and water as a transparent medium. The roughness of the sample increased from $R_{\mathrm{a}}=0.23 \mu \mathrm{m}$ to $R_{\mathrm{a}}=0.63 \mu \mathrm{m}$ after LSP. The surface hardness of the alloy increased from $40 \mathrm{HV}$ (substrate) to $63 \mathrm{HV}$ (after shock peening) because of the LSP-induced cold working at the surface. The depth of the LSP-induced hardened region was found to be $0.8 \mathrm{~mm}$. LSP also resulted in 

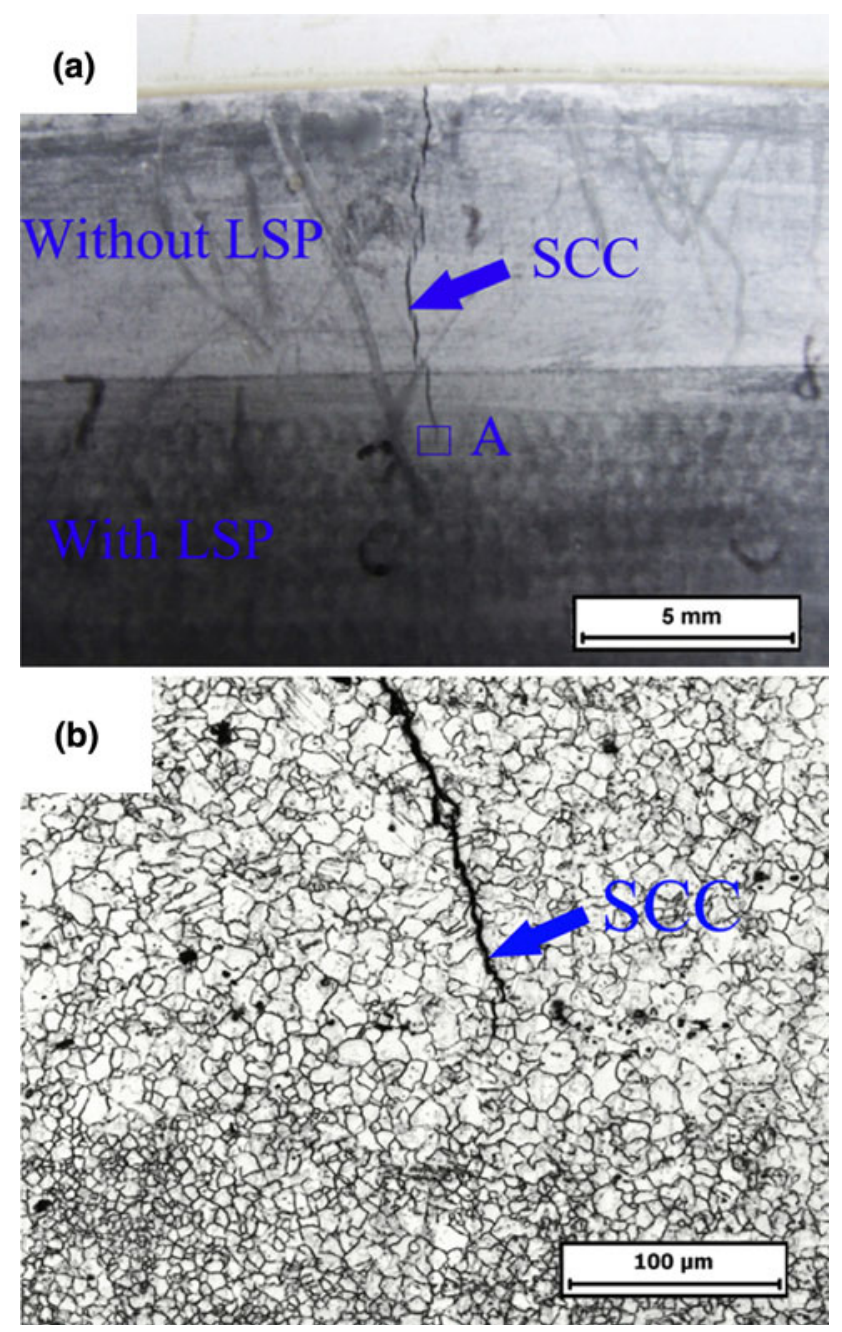

Fig. 17. (a) Optical micrograph showing SCC sample having regions with and without LSP treatment. (b) Micrograph showing crack-free and refined LSP treated region, and cracked region without LSP treatment $^{74}$ (Reprinted with permission from Elsevier).

modification of the stress state at the surface. The residual stress, measured using XRD methods, on the as-received surface was $17 \mathrm{MPa}$. After LSP, a compressive residual stress of $-146 \mathrm{MPa}$ was observed at the surface. LSP also improved corrosion resistance of the alloy because of the elimination of surface microporosities. Zhang et al. ${ }^{74}$ investigated the effect of LSP on stress corrosion cracking (SCC) behavior of AZ31B alloy. LSP resulted in the refinement of grains with average grain size of $5.8 \mu \mathrm{m}$ after four laser impacts. The surface compressive residual stresses increased with an increasing number of laser impacts. The compressive stresses of $-190 \mathrm{MPa}$ and $-240 \mathrm{MPa}$ were formed on the surface after LSP using two and four impacts, respectively. The immersion of the sample in the 1 wt.\% $\mathrm{NaOH}$ for $500 \mathrm{~h}$ at room temperature resulted in cracking primarily in the region without LSP. Similar cracking was not observed in the laser shock peened region of the sample indicating effectiveness of LSP in retarding initiation of SCC in Mg alloys (Fig. 17). Using finiteelement methods, Jiang et al. ${ }^{75}$ modeled the LSP of AZ31B and ZK60 Mg alloys (laser spot of $5 \mathrm{~mm}$, pulse duration of $23 \mathrm{~ns}$, and shock wave pressure of $2 \mathrm{GPa}$ ) and predicted the fatigue life. An increase in fatigue life cycles from $8.62 \times 10^{4}$ (ZK60 substrate) to $1.49 \times 10^{5}$ (one side) and $1.54 \times 10^{5}$ (both sides) after LSP was predicted. The predicted increase in fatigue strength was mainly caused by hardening of the surface and generation of compressive residual strength near the surface of the sample.

\section{CONCLUSIONS}

Laser surface engineering is expected to play an important role in improving the surface properties of $\mathrm{Mg}$ alloys. Most of the laser surface engineering approaches such as LSM, LSA, LCS, LSC, and LSP have demonstrated effectiveness in improving corrosion, wear, and fatigue properties of $\mathrm{Mg}$ alloys. These property improvements are primarily the result of modification of composition (solute enrichment caused by selective vaporization and extension of solubility limit), microstructure (grain refinement, formation of desired intermetallic or new phases, and uniform distribution of phases) and state of stress (introduction of residual stresses at the surface). Although the technological advantages of the laser surface engineering approaches are evident, significant efforts needs to be directed toward understanding the laser interaction effects with $\mathrm{Mg}$ alloys. Detailed experimental and computational investigations on laser-material interaction effects such as selective vaporization of elements, grain refinement, melt pool dilution, second-particle penetration, residual stresses, and solidification defects needs to be conducted to advance the understanding. Whereas it is possible to modify large area of $\mathrm{Mg}$ substrates using overlapping parallel tracks of laser modified regions, the microstructure and properties of these overlapping regions are expected to influence the overall performance of the laser modified surfaces.

\section{ACKNOWLEDGEMENT}

The authors acknowledge support from the U.S. National Science Foundation (NSF CAREER Award No.: CMMI-1149079).

\section{REFERENCES}

1. K. Kubota, M. Mabuchi, and K. Higashi, J. Mater. Sci. 34, 2255 (1999).

2. M.P. Staiger, A.M. Pietak, J. Huadmai, and G. Dias, Biomaterials 27, 1728 (2006)

3. B. Landkof, Magnesium Alloys and their Applications (Berlin: Wiley-VCH, 2006), p. 168.

4. S. Agnew, JOM 56, 20 (2004).

5. E. Aghion, B. Bronfin, and D. Eliezer, J. Mater. Process. Technol. 117, 381 (2001).

6. B.B. Clow, Adv. Mater. Processes 150, 33 (1996).

7. M. Kulekci, Int. J. Adv. Manuf. Technol. 39, 851 (2008).

8. H. Watarai, Sci. Technol. Trends 18, 84 (2006). 
9. R. Steve, Technology for Magnesium Castings: Design, Products \& Applications (Schaumburg, IL: American Foundry Society, 2009), p. 1.

10. J.E. Gray and B. Luan, J. Alloy. Compd. 336, 88 (2002).

11. R. Ambat and W. Zhou, Surf. Coat. Technol. 179, 124 (2004).

12. H. Iwasawa, J. Surf. Finish. Soc. Jpn. 53, 185 (2002).

13. Y.W. Song, D.Y. Shan, and E.H. Han, Electrochim. Acta 53, 2135 (2008)

14. K. Brunelli, M. Dabalà, I. Calliari, and M. Magrini, Corros. Sci. 47, 989 (2005).

15. M.A. Gonzalez-Nunez, C.A. Nunez-Lopez, P. Skeldon, G.E. Thompson, H. Karimzadeh, P. Lyon, and T.E. Wilks, Corros. Sci. 37, 1763 (1995).

16. A.L. Rudd, C.B. Breslin, and F. Mansfeld, Corros. Sci. 42, 275 (2000).

17. S.Q. Xu, Q. Li, Y.H. Lu, B. Chen, and J.M. Fan, Surf. Eng. 26, 328 (2010).

18. R. Arrabal, A. Pardo, M. Merino, M. Mohedano, P. Casajús, and E. Matykina, J. Therm. Spray Technol. 20, 569 (2011).

19. H. Pokhmurska, B. Wielage, T. Lampke, T. Grund, M. Student, and N. Chervinska, Surf. Coat. Technol. 202, 4515 (2008).

20. M. Parco, L. Zhao, J. Zwick, K. Bobzin, and E. Lugscheider, Surf. Coat. Technol. 201, 3269 (2006).

21. C. Christoglou, N. Voudouris, G.N. Angelopoulos, M. Pant, and W. Dahl, Surf. Coat. Technol. 184, 149 (2004).

22. M. Li, Y. Cheng, Y.F. Zheng, X. Zhang, T.F. Xi, and S.C. Wei, Appl. Surf. Sci. 258, 3074 (2012).

23. T. Ishizaki, J. Hieda, N. Saito, N. Saito, and O. Takai, Electrochim. Acta 55, 7094 (2010).

24. H. Altun and S. Sen, Mater. Charact. 58, 917 (2007).

25. A.N. Samant and N.B. Dahotre, J. Eur. Ceram. Soc. 29, 969 (2009).

26. N.B. Dahotre, Lasers in Surface Engineering (Materials Park, OH: ASM International, 1998).

27. J.D. Majumdar, I. Manna, and Sadhana, Acad. Proc. Eng. Sci. 28, 495 (2003)

28. A.K. Mondal, S. Kumar, C. Blawert, and N.B. Dahotre, Surf. Coat. Technol. 202, 3187 (2008).

29. D. Dube, M. Fiset, A. Couture, and I. Nakatsugawa, Mater. Sci. Eng. A 299, 38 (2001).

30. J.D. Majumdar, R. Galun, B.L. Mordike, and I. Manna, Mater. Sci. Eng. A 361, 119 (2003).

31. G. Abbas, Z. Liu, and P. Skeldon, Appl. Surf. Sci. 247, 347 (2005).

32. X. Lv, H. Liu, Y. Wang, Y. Lu, G. Li, and J. An, J. Mater. Eng. Perform. 20, 1015 (2011).

33. S.Y. Liu, J.D. Hu, Y. Yang, Z.X. Guo, and H.Y. Wang, Appl. Surf. Sci. 252, 1723 (2005).

34. G. Abbas, L. Li, U. Ghazanfar, and Z. Liu, Wear 260, 175 (2006).

35. L.F. Guo, T.M. Yue, and H.C. Man, J. Mater. Sci. 40, 3531 (2005).

36. Y. Gao, C. Wang, M. Yao, and H. Liu, Mater. Corros. 58, 463 (2007).

37. G.L. Makar, J. Kruger, and K. Sieradzki, Corros. Sci. 34, 1311 (1993).

38. C.W. Draper and C.A. Ewing, J. Mater. Sci. 19, 3815 (1984).

39. R.W. Galun and B.L. Mordike (Paper presented at the Proceedings of the Third International Magnesium Conference, Manchester, U.K., 10-12 April 1996), pp. 699-711.

40. K. Murayama, A. Suzuki, T. Takagi, S. Kamado, Y. Kojima, and H. Hiraga, Magnesium Alloys 2003, Pts. 1 and 2, ed. Y. Kojima, T. Aizawa, K. Higashi, and S. Kamado (Lebanon, NH: Trans Tech Publications, 2003), pp. 969-974.
41. Q. Ming, L. Da, and J. Chang, Sci. Technol. Adv. Mater. 9, 025002 (2008).

42. J.D. Majumdar and I. Manna, Scr. Mater. 62, 579 (2010).

43. S.R. Paital, A. Bhattacharya, M. Moncayo, Y.H. Ho, K. Mahdak, S. Nag, R. Banerjee, and N.B. Dahotre, Surf. Coat. Technol. 206, 2308 (2012).

44. C. Chen, D. Wang, and M. Wang, Chin. Opt. Lett. 1, 160 (2003).

45. A.N. Samant, B. Du, S.R. Paital, S. Kumar, and N.B. Dahotre, J. Mater. Proc. Technol. 209, 5060 (2009).

46. L.A. Dobrzanski, J. Domaga, T. Tanski, A. Klimpel, and D. Janicki, Arch. Mater. Sci. Eng. 30, 113 (2008).

47. J.D. Majumdar, B.R. Chandra, R. Galun, B.L. Mordike, and I. Manna, Compos. Sci. Technol. 63, 771 (2003).

48. J.D. Majumdar, R. Galun, B.L. Mordike, B.R. Chandra, and I. Manna, Lasers Eng. 16, 349 (2006).

49. L.A. Dobrzanski, J. Domagała, T. Tanski, A. Klimpel, D. Janicki, and J. Achieve, Mater. Manuf. Eng. 28, 179 (2008).

50. R. Subramanian, S. Sircar, and J. Mazumder, J. Mater. Sci. 26, 951 (1991).

51. L. Sexton, S. Lavin, G. Byrne, and A. Kennedy, J. Mater. Process. Technol. 122, 63 (2002).

52. M. Zhong and W. Liu, Proc. Inst. Mech. Eng. C 224, 1041 (2010).

53. T.M. Yue, Y.P. Su, and H.O. Yang, Mater. Lett. 61, 209 (2007).

54. T. Yue and Y. Su, J. Mater. Sci. 42, 6153 (2007)

55. T.M. Yue and Y.P. Su, Appl. Surf. Sci. 255, 1692 (2008).

56. T.M. Yue and T. Li, Surf. Coat. Technol. 202, 3043 (2008).

57. Y. Jun, G.P. Sun, H.-Y. Wang, S.Q. Jia, and S.S. Jia, J. Alloy. Compd. 407, 201 (2006).

58. Y.H. Liu, Z.X. Guo, Y. Yang, H.Y. Wang, J.D. Hu, Y.X. Li, A.N. Chumakov, and N.A. Bosak, Appl. Surf. Sci. 253, 1722 (2006).

59. Y.L. Gao, C.S. Wang, H.J. Pang, H.B. Liu, and M. Yao, Appl. Surf. Sci. 253, 4917 (2007).

60. P. Volovitch, J.E. Masse, A. Fabre, L. Barrallier, and W. Saikaly, Surf. Coat. Technol. 202, 4901 (2008).

61. B. Bronfin, M. Katsir, and E. Aghion, Mater. Sci. Eng. A 302,46 (2001)

62. J.D. Majumdar, B.R. Chandra, B.L. Mordike, R. Galun, and I. Manna, Surf. Coat. Technol. 179, 297 (2004).

63. T.M. Yue, A.H. Wang, and H.C. Man, Scr. Mater. 40, 303 (1999).

64. M. Hazra, A.K. Mondal, S. Kumar, C. Blawert, and N.B. Dahotre, Surf. Coat. Technol. 203, 2292 (2009).

65. Y-l Gao, C.-S. Wang, M. Yao, and H.-B. Liu, Appl. Surf. Sci. 253, 5306 (2007).

66. A. Fabre and J.E. Masse, Tribol. Int. 46, 247 (2012).

67. Y. Yang and H. Wu, Mater. Lett. 63, 19 (2009).

68. K.-J. Huang, L. Yan, C.-S. Wang, C.-S. Xie, and C.-R. Zhou, Trans. Nonferr. Met. Soc. China 20, 1351 (2010).

69. Z.G. Mei, L.F. Guo, and T.M. Yue, J. Mater. Process. Technol. 161, 462 (2005)

70. G. Hammersley, L.A. Hackel, and F. Harris, Opt. Lasers Eng. 34, 327 (2000).

71. J.M. Yang, Y.C. Her, N. Han, and A. Clauer, Mater. Sci. Eng. A 298, 296 (2001)

72. P. Peyre and R. Fabbro, Opt. Quant. Electron. 27, 1213 (1995).

73. J.W.J. Chen, X. Chen, and W. Lei, ADTM2010.org (2010).

74. Y. Zhang, J. You, J. Lu, C. Cui, Y. Jiang, and X. Ren, Surf. Coat. Technol. 204, 3947 (2010).

75. S.Q. Jiang, J.Z. Zhou, Y.J. Fan, S. Huang, and J.F. Zhao, Mater. Sci. Forum 626-627, 393 (2009). 